\title{
Differences in Susceptibility of Arabidopsis Ecotypes to Crown Gall Disease May Result from a Deficiency in T-DNA Integration
}

\author{
Jaesung Nam, ${ }^{a}$ Ann G. Matthysse, ${ }^{b}$ and Stanton B. Gelvina, \\ aDepartment of Biological Sciences, Purdue University, West Lafayette, Indiana 47907-1392 \\ ${ }^{b}$ Department of Biology, University of North Carolina, Chapel Hill, North Carolina 27599-3280
}

\begin{abstract}
We show that among ecotypes of Arabidopsis, there is considerable variation in their susceptibility to crown gall disease. Differences in susceptibility are heritable and, in one ecotype, segregate as a single major contributing locus. In several ecotypes, recalcitrance to tumorigenesis results from decreased binding of Agrobacterium to inoculated root explants. The recalcitrance of another ecotype occurs at a late step in T-DNA transfer. Transient expression of a T-DNAencoded $\beta$-glucuronidase gus $A$ gene is efficient, but the ecotype is deficient in crown gall tumorigenesis, transformation to kanamycin resistance, and stable GUS expression. This ecotype is also more sensitive to $\gamma$ radiation than is a susceptible ecotype. DNA gel blot analysis showed that after infection by Agrobacterium, less T-DNA was integrated into the genome of the recalcitrant ecotype than was integrated into the genome of a highly susceptible ecotype.
\end{abstract}

\section{INTRODUCTION}

Agrobacterium is a soil-borne phytopathogen that induces the neoplastic disease crown gall on most dicotyledonous plants and on some species of monocots and gymnosperms (DeCleene and DeLey, 1976). Although Agrobacterium is one of many bacterial plant pathogens, the symptoms induced on susceptible plants differ from those induced by other bacterial pathogens, such as most Pseudomonas, Erwinia, and Xanthomonas species. Inoculation of wounded plants with virulent agrobacteria leads to neoplastic growth of the infected host cells, although in certain instances tissue necrosis can occur (Pu and Goodman, 1992; Deng et al., 1995). In addition, Agrobacterium fails to elicit a typical hypersensitive response in resistant plants. Despite the lack of tumorous growth, resistant plants may still show a healing response at the infected wound site.

The basic mechanism of tumorigenesis by Agrobacterium involves the transfer of specific T-DNA molecules from the bacterial tumor-inducing ( $\mathrm{Ti}$ ) plasmid into the plant cell. Integration of T-DNA into the plant genome and the expression of T-DNA-encoded genes result in the overproduction of auxins and cytokinins, which are plant growth-regulating hormones. Crown gall tumors subsequently develop at infection sites where unregulated plant cell division occurs (reviewed in Binns and Thomashow, 1988; Ream, 1989; Gelvin, 1990, 1992; Hooykaas and Beijersbergen, 1994; Zupan and Zambryski, 1995).

1 To whom correspondence should be addressed. E-mail gelvin@bilbo.bio.purdue.edu; fax 317-496-1496.
For several decades, scientists have studied intensively the mechanisms by which Agrobacterium transfers T-DNA to the plant cell and induces neoplastic cell growth. By using a large number of Agrobacterium strains and mutants, we now understand reasonably well many of the early events in crown gall tumorigenesis, including induction of the virulence (vir) genes (Winans, 1992), processing of the T-DNA from the Ti plasmid (Stachel et al., 1986; Filichkin and Gelvin, 1993), and formation of bacterial channels for exporting the T-DNA (Thompson et al., 1988; Ward et al., 1988; Kuldau et al., 1990), possibly as a DNA-protein complex (known as the T-complex; Howard and Citovsky, 1990). In contrast, little is known about plant host factors involved in crown gall tumorigenesis. There are at least three obstacles that Agrobacterium must overcome to transform a plant cell. First of all, Agrobacterium must transfer T-DNA into the cytoplasm of plant cells after the DNA has crossed the plant cell wall and plasma membrane. We now know that T-DNA enters the plant as a single-stranded DNA molecule (Tinland et al., 1994; Yusibov et al., 1994). Before genes encoded by the T-DNA can be expressed, however, the T-DNA must reach the plant nucleus. These events may be aided by nuclear localization signals found in VirD2 and VirE2 proteins that may accompany the T-DNA into the plant cell (HerreraEstrella et al., 1990; Citovsky et al., 1992, 1994; Howard et al., 1992; Shurvinton et al., 1992; Tinland et al., 1992; Koukolikova-Nicola et al., 1993; Rossi et al., 1993). Finally, the T-DNA must become stabilized by integration into the plant genome. T-DNA integration may occur by illegitimate 
recombination (Matsumoto et al., 1990; Gheysen et al., 1991; Mayerhofer et al., 1991; Ohba et al., 1995). Should any of these steps in the infection cascade fail, the result would be an abortive infection. Currently, however, we know little about whether or what kind of specific plant genes are involved in these processes.

Several studies have identified naturally occurring variations in susceptibility to crown gall disease in a number of plant species, including cucurbits (Smarrelli et al., 1986), pea (Robbs et al., 1991), soybean (Owens and Cress, 1984; Bailey et al., 1994; Mauro et al., 1995), and grapevine (Szegedi and Kozma, 1984). The basic mechanism for variation in these species is still not known; however, the resistant phenotype is transmitted to progeny in self-crossing or in reciprocal crosses, confirming that this character is a heritable trait. In grapevine, resistance seems to be inherited as a single dominant gene, but in other species, resistance is recessive and is not inherited in a simple fashion. In soybean, for example, susceptibility is a dominant quantitative trait (Bailey et al., 1994; Mauro et al., 1995).

Researchers in a number of laboratories have used different ecotypes of Arabidopsis to investigate differential host responses to various strains or races of bacteria (Simpson and Johnson, 1990; Davis et al., 1991; Debener et al., 1991; Dong et al., 1991; Tsuji et al., 1991; Whalen et al., 1991; Bent et al., 1992; Dangl et al., 1992; Yu et al., 1993; Aufsatz and Grimm, 1994), fungi (Koch and Slusarenko, 1990; Holub et al., 1995; Fuchs and Sacristan, 1996), and viruses (Leisner and Howell, 1992; Simon et al., 1992; Leisner et al., 1993; Lee et al., 1994). Our goal was to determine whether differences also exist among Arabidopsis ecotypes with regard to tumorigenesis caused by Agrobacterium and what the biochemical and genetic bases of these differences are. Therefore, we developed an in vitro root inoculation assay and screened Arabidopsis ecotypes for susceptibility or resistance to crown gall disease. We have identified several ecotypes that are hypersusceptible to crown gall tumorigenesis as well as other ecotypes that are recalcitrant (less susceptible) to tumorigenesis. We describe here a number of assays to identify steps in the tumorigenesis process that may be deficient in the recalcitrant ecotypes. Interestingly, we have identified one ecotype that appears to permit T-DNA transfer and nuclear transport but is deficient in T-DNA integration.

\section{RESULTS}

\section{Response of Arabidopsis Ecotypes to Different Agrobacterium Strains}

We initially characterized the response of 11 Arabidopsis ecotypes to four different Agrobacterium strains by using an in vitro root segment infection tumorigenesis assay. These ecotypes are Aua/Rhon (Aa-0), Bensheim/Bergstrasse (Be-0),
Columbia (Col-0), C-24, Landsberg erecta (Ler), Lipowiec/ Chrzanow (Lip), Nossen (No-0), Oy-0, RLD, and two unidentified ecotypes (UE), UE-1 and UE-2.

We preincubated sterile root explants from Arabidopsis plants on callus-inducing medium (CIM) for 1 day before cutting them into segments and infecting them with Agrobacterium. In general, preincubation on CIM is a critical step for the efficient transformation of Arabidopsis when this assay is used, presumably because in root explants, competent cells are present in the dedifferentiating pericycle that is produced after phytohormone treatment (Sangwan et al., 1992). We tested four Agrobacterium strains that all had the same C58 chromosomal background. Agrobacterium strain A136 lacks a Ti plasmid and is therefore avirulent, whereas the virulent strains Agrobacterium A348, A208, and A281 contain the octopine-type $\mathrm{Ti}$ plasmid PTiA6, the nopalinetype Ti plasmid pTiT37, or the agropine-type supervirulent $\mathrm{Ti}$ plasmid pTiBo542, respectively. We chose Agrobacterium A208 as the best strain for further study.

From among the 11 Arabidopsis ecotypes studied, UE-1 appeared recalcitrant to tumorigenesis caused by Agrobacterium strain A208. Usually, UE-1 did not respond to inoculation. Occasionally, a few small yellow tumorous calli lacking teratomas developed. In contrast, infected root segments of ecotype Aa- 0 consistently developed large green tumors with teratomas (Figure 1A) when this assay was used. In addition, ecotype UE-1 exhibited a greatly reduced tumorigenesis response, relative to ecotype $\mathrm{Aa}-0$, when we inoculated bacteria onto a wounded flower stalk (Figure 1B). Therefore, we concentrated our initial analyses on these two ecotypes.

\section{Comparison of Metabolic Activity between Arabidopsis Ecotypes $A a-0$ and UE-1}

We investigated various aspects of plant metabolism to determine whether the differences in susceptibility to crown gall disease between ecotypes $\mathrm{Aa}-\mathrm{O}$ and $\mathrm{UE}-1$ reflected differences in basic metabolic processes. We compared the rates of ${ }^{14} \mathrm{C}$-amino acid and ${ }^{3} \mathrm{H}$-thymidine incorporation into macromolecules, the ability of root segments from the two ecotypes to produce and secrete compounds that could induce Agrobacterium vir genes, and the response of root segments from the two ecotypes to different concentrations of various auxins and cytokinins. We did not observe any major differences for any of these processes between the two ecotypes (data not shown).

\section{Efficiency of T-DNA Transfer to Cells of the Arabidopsis Ecotypes Aa-0 and UE-1}

To investigate whether the difference in tumorigenesis between Arabidopsis ecotypes $A a-0$ and $U E-1$ results from a deficiency in T-DNA transfer from Agrobacterium to UE-1 cells, we investigated the transient T-DNA-mediated trans- 


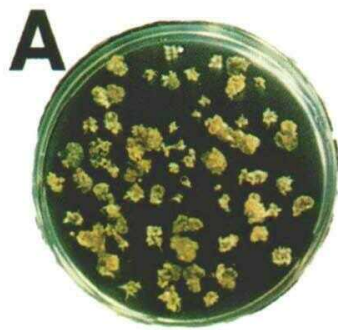

\section{Aa-0}
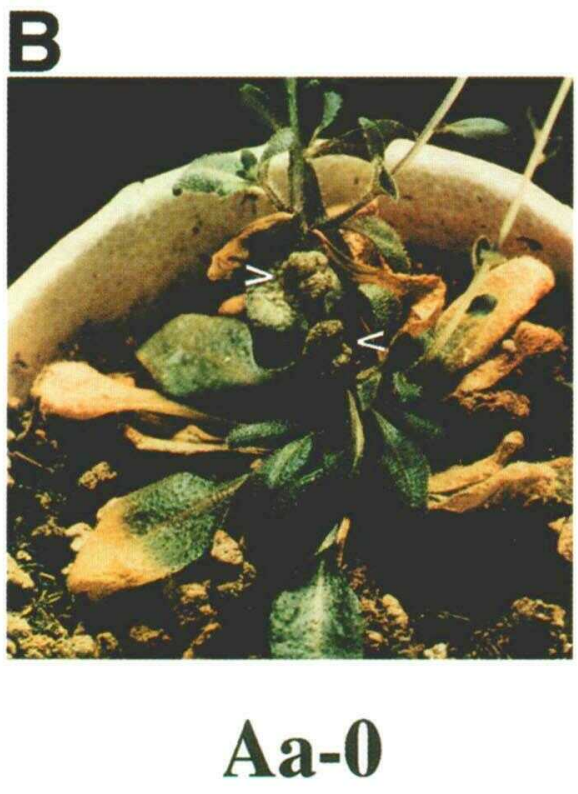
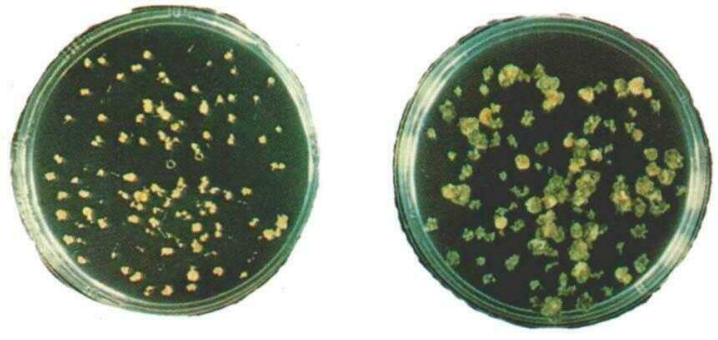

\section{UE-1 Aa-0 x UE-1}
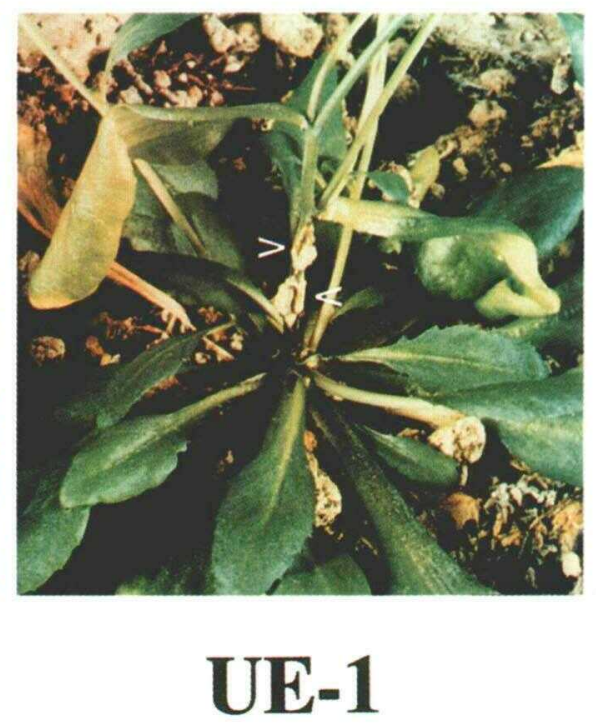

Figure 1. Tumorigenesis of Agrobacterium Strain A208 on Root Explants and Flower Bolts of Arabidopsis Ecotypes Aa-0 and UE-1.

(A) Sterile root segments of Arabidopsis ecotypes UE-1, Aa- 0 , and the $F_{1}$ progeny of a cross between these two ecotypes were cocultivated with Agrobacterium strain A208 for 2 days and then transferred to Murashige and Skoog (MS) basal medium containing timentin. The plates were photographed after 4 weeks.

(B) Flower bolts of Arabidopsis ecotypes UE-1 and Aa-0 were inoculated with Agrobacterium strain A208, and the plants were photographed after 4 weeks. Arrowheads indicate the sites of inoculation.

fer to and expression of a $\beta$-glucuronidase gus $A$ gene in the cells of these two ecotypes. We characterized GUS expression in Arabidopsis cells by using both a qualitative histochemical staining assay and a quantitative fluorometric assay. We introduced the binary T-DNA vector pCNL65 (Liu et al., 1992) into Agrobacterium strain A208. This vector contains a gus $A$ gene harboring an intron. gus $A$ is under the control of the cauliflower mosaic virus (CaMV) $35 \mathrm{~S}$ promoter. The intron in the gusA gene permits expression of GUS activity only in plant cells but not in the bacteria (Liu et al., 1992). Figure 2 shows that root explants of ecotypes Aa-0 and UE-1 showed approximately equal numbers and intensity of blue spots after infection by Agrobacterium A208(pCNL65) for 7 days and histochemical staining with X-gluc. In this in- fection protocol, cocultivation was performed for 2 days, followed by an additional 5 days of incubation in the presence of antibiotics to kill the bacteria.

Stained cells were preferentially localized at the cut termini of root explants because these cells were preferentially activated by wounding and accessible for T-DNA transfer. In addition, we quantitated GUS activity in these infected roots by using a fluorometric 4-methylumbelliferyl $\beta$-D-galactoside (MUG) assay. Both ecotypes displayed a similar level of GUS expression (1100 to 1500 GUS units) when we used this assay. GUS activity detected early after infection most probably represents transient expression of T-DNA that is not yet integrated into the plant genome (Janssen and Gardner, 1989; Liu et al., 1992; Narasimhulu et al., 1996). 

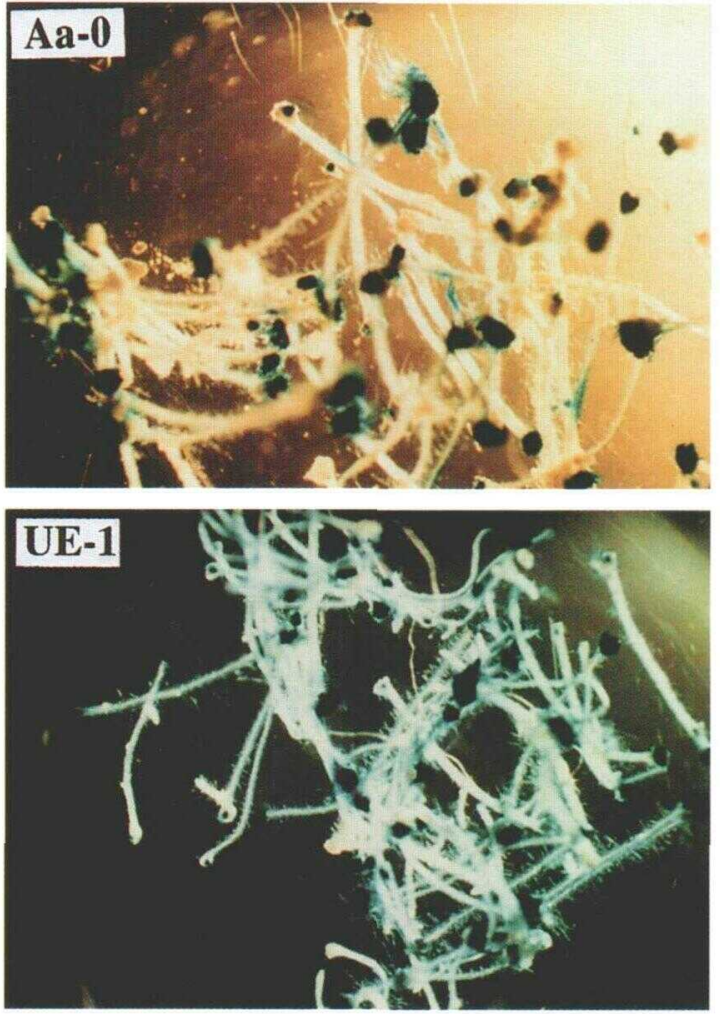

Figure 2. Histochemical Staining of Transient GUS Expression in Arabidopsis Root Segments.

(Top) Sterile root segments of Arabidopsis ecotype Aa- 0 were infected with Agrobacterium strain A208 harboring the plasmid pCNL65.

(Bottom) Sterile root segments of Arabidopsis ecotype UE-1 were infected with Agrobacterium strain A208 harboring the plasmid pCNL65 After 2 days, the roots were transferred to MS basal medium containing timentin. After an additional 5 days, the root segments were stained with X-gluc, as described in Methods.

These data indicate that the efficiency of T-DNA transfer to and expression in the plant nucleus is similar for ecotypes $\mathrm{Aa}-\mathrm{O}$ and $\mathrm{UE}-1$. Therefore, we conclude that the difference in tumorigenesis between these ecotypes does not result from a deficiency of T-DNA transfer or nuclear targeting in the ecotype UE-1.

\section{Stable GUS Expression and Kanamycin Resistance in Infected $\mathrm{Aa}-\mathrm{O}$ and $\mathrm{UE}-1 \mathrm{C}$ Cells}

The finding that ecotypes $\mathrm{Aa}-\mathrm{O}$ and $\mathrm{UE}-1$ showed an approximately equal amount of transient GUS expression but exhibited a different tumorigenesis response to Agrobacterium infection suggested to us that ecotype UE-1 may be deficient in some step of tumorigenesis that involves the stabilization of T-DNA and/or its expression in infected plant cells. To test this hypothesis, we examined two additional transformation events that require stable integration and expression of T-DNA in the plant cells: stable GUS expression and kanamycin-resistant growth of calli derived from infected Arabidopsis root segments.

We cocultivated root segments of the ecotypes Aa-0 and UE- 1 for 2 days with A208(pCNL65) and then transferred the root segments to $\mathrm{CIM}$ to induce calli without selection or to CIM containing kanamycin to select stable transformants. Figure 3 shows that only root segments from ecotype Aa-0 (Figure 3B) but not from ecotype UE-1 (Figure 3D) efficiently developed calli on CIM containing kanamycin, although root segments of both ecotypes generated calli on CIM lacking kanamycin (Figures 3A and $3 \mathrm{C}$ ). A few kanamycin-resistant calli developed later in ecotype UE-1 (data not shown). In addition, we investigated stable GUS expression by X-gluc staining of calli derived from root segments grown on CIM without kanamycin selection. Figure 4 shows that calli from

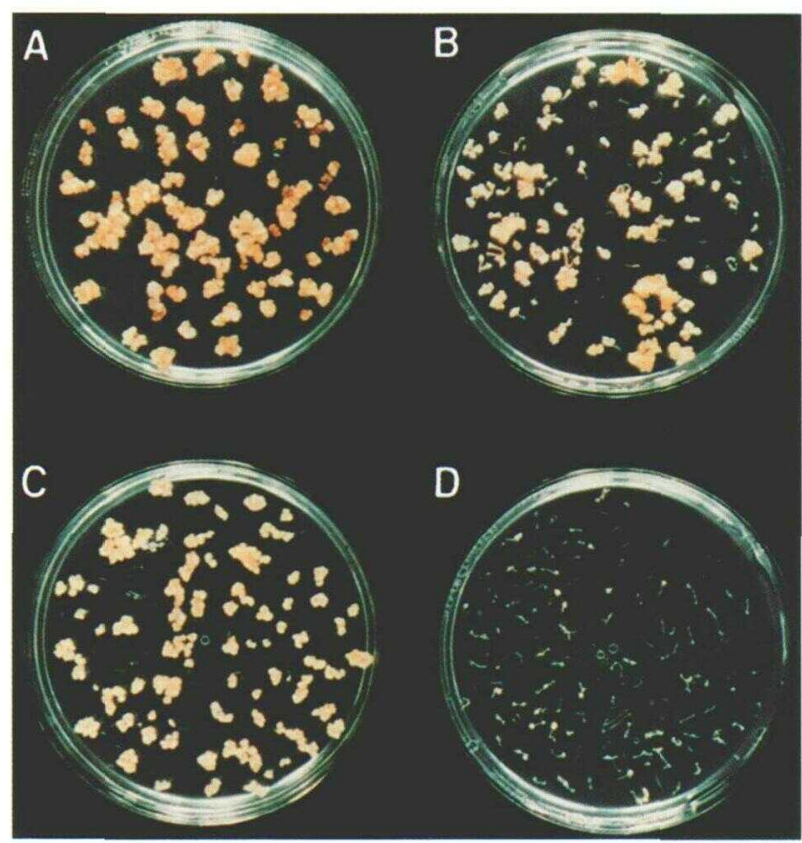

Figure 3. Selection of Kanamycin-Resistant Calli of Different Arabidopsis Ecotypes.

(A) and (B) Sterile root segments of Arabidopsis ecotype Aa-0 were infected with Agrobacterium strain A208 harboring the plasmid pCNL65.

(C) and (D) Sterile root segments of Arabidopsis ecotype UE-1 were infected with Agrobacterium strain A208 harboring the plasmid pCNL65.

After 2 days, the roots were transferred to CIM either lacking ([A] and $[\mathrm{C}]$ ) or containing ([B] and [D]) kanamycin, and the plates were incubated for 4 weeks, as described in Methods. 

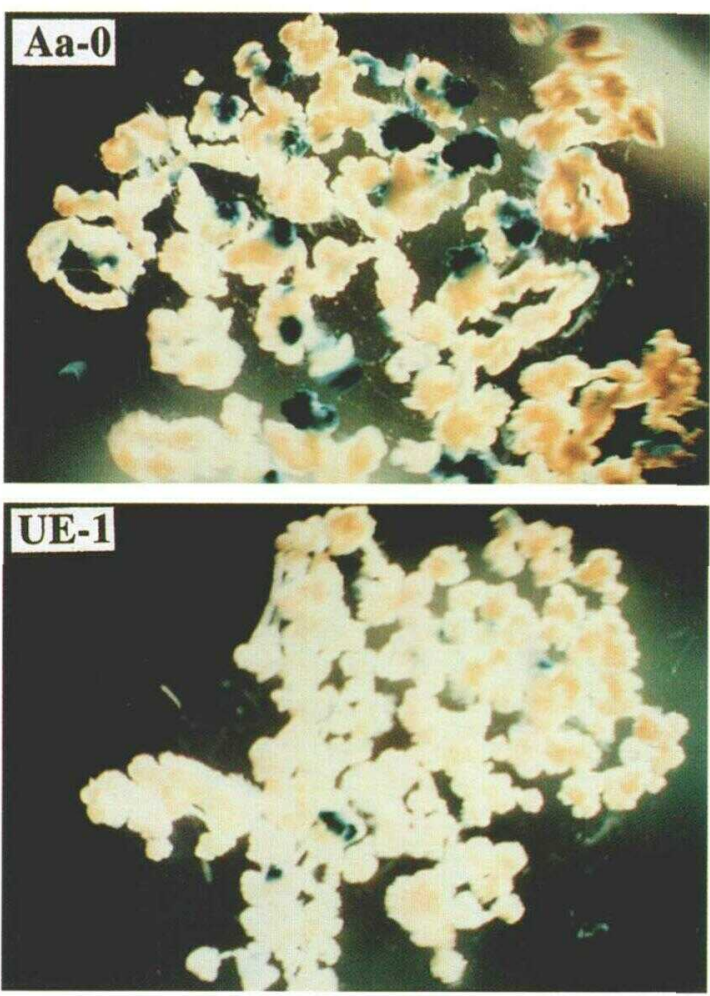

Figure 4. Histochemical Staining of Stable GUS Expression in Calli Derived from Infected Arabidopsis Root Segments.

(Top) Sterile root segments of Arabidopsis ecotype Aa-0 were infected with Agrobacterium strain A208 harboring the plasmid pCNL65.

(Bottom) Sterile root segments of Arabidopsis ecotype UE-1 were infected with Agrobacterium strain A208 harboring the plasmid pCNL65.

After 2 days, the roots were transferred to CIM containing timentin. After an additional 4 weeks, calli derived from the root segments were stained with X-gluc, as described in Methods.

ecotype UE-1 showed considerably fewer and smaller blue spots than did calli from ecotype Aa-0. Although the quantitation of GUS activity by counting the number of blue staining areas of tissue is problematic, the representative stained tissues in Figure 4 show an approximately sixfold difference between ecotypes Aa-0 (19 stained areas) and UE-1 (three stained areas).

To investigate more thoroughly the kinetics of GUS expression in Arabidopsis ecotypes Aa-0 and UE-1, we inoculated root segments with the nontumorigenic nopaline-type Agrobacterium strain GV3101 containing the T-DNA binary vector pBISN1. pBISN1 (Narasimhulu et al., 1996) is based on $\mathrm{pBI} 101$, but the expression of the intron-containing gus $A$ gene within the T-DNA is directed by a "super promoter" (a chimeric promoter composed of three octopine synthase- activating elements and the mannopine synthase 2 ' activator plus promoter; $\mathrm{Ni}$ et al., 1995). This plasmid permitted us to detect GUS activity in the termini of infected root segments after only 2 days of cocultivation. By using a nontumorigenic Agrobacterium strain and growing calli under nonselective conditions, we avoided the possibility of stably transformed tumorous cells outgrowing transiently transformed nontumorous cells.

Figure 5 shows that root segments of both ecotypes Aa-0 and UE-1 first expressed detectable GUS activity 2 days after the start of cocultivation. For both ecotypes, GUS activity increased greatly 3 days after infection, after which there was a decline in GUS activity. In several repetitions of this experiment, roots of ecotype UE-1 repeatedly expressed approximately twice as much GUS activity as did roots of ecotype Aa-0. GUS activity in the roots of UE-1 continued to decrease during the course of this experiment and other repetitions of this experiment. However, in ecotype Aa-0, GUS activity increased 25 to 30 days after the start of cocultivation. The increase in GUS activity in the roots of ecotype Aa- 0 most likely results from expression of integrated copies of the gusA gene (Janssen and Gardner, 1989; Narasimhulu et al., 1996). The length of time for ecotype UE-1 to lose GUS activity most likely reflects the stability of the GUS enzyme (Jefferson et al., 1987). These results, taken together with the tumorigenesis, kanamycin resistance, and transient GUS expression results, strongly suggest that the main cause of the difference in tumorigenesis between $\mathrm{Aa}-\mathrm{O}$ and UE-1 is a difference in T-DNA integration into the plant genome and/or its stable expression.

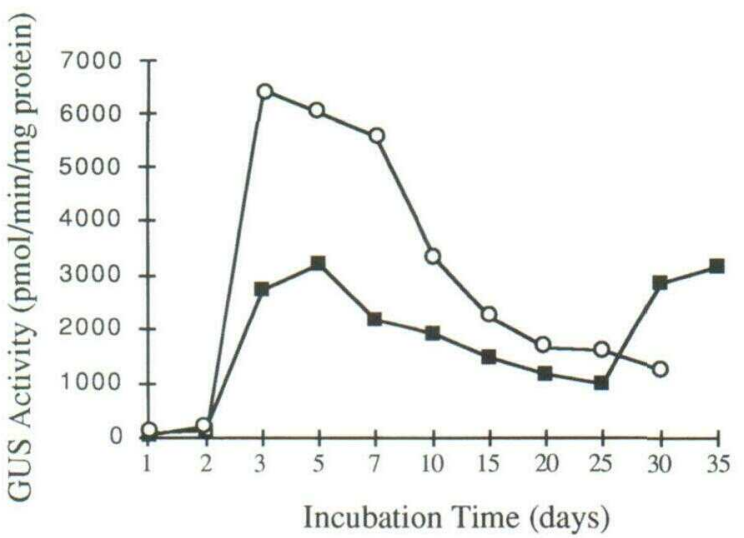

Figure 5. Kinetics of GUS Expression in Arabidopsis Root Segments.

Root segments of Arabidopsis ecotypes Aa-0 $(O)$ and UE-1 (四) were infected with Agrobacterium strain GV3101 containing the plasmid pBISN1. After 2 days, the tissue was transferred to CIM containing timentin. After various periods of time, samples were assayed for GUS activity by using a quantitative MUG fluorometic assay. The times indicate days after initial infection. 


\section{Efficiency of T-DNA Integration into the Genomes of Ecotypes Aa-0 and UE-1}

The results presented above suggest that the basis for the recalcitrance of UE-1 to tumorigenesis could be a deficiency of T-DNA integration into the plant genome. To investigate this possibility, we infected root segments of ecotypes Aa-0 and UE-1 with A208(pCNL65) and grew calli on CIM without selection. These calli were used to initiate cell suspensions grown in liquid CIM. The suspensions were composed of a mixture of transformed and nontransformed cells. Figure $6 \mathrm{~A}$ shows that when first hybridized with a gusA gene probe, high molecular weight DNA from cell lines of infected ecotype Aa-0 showed a much stronger signal than did DNA from ecotype UE-1. Densitometric analysis of the autoradio-

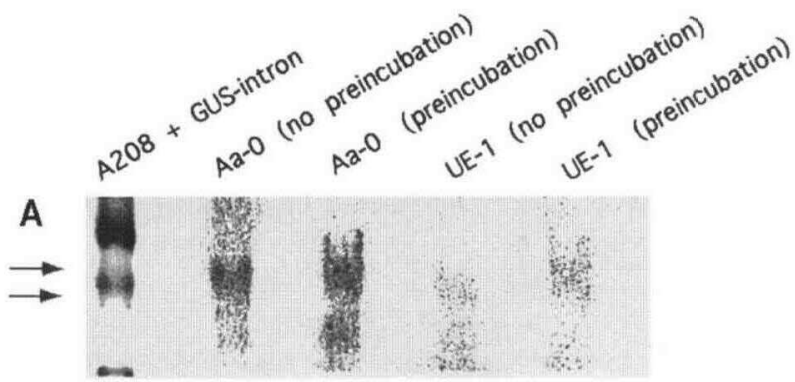

B

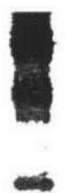

C
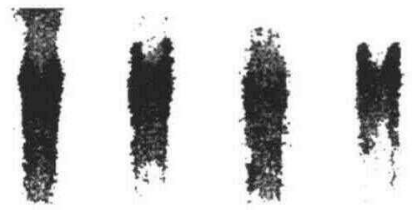

Figure 6. Integration of T-DNA into the Genomes of Different Arabidopsis Ecotypes.

Root segments of Arabidopsis ecotypes Aa- 0 and UE- 1 were either incubated on CIM for 1 day before infection or infected directly with Agrobacterium strain A208 containing the plasmid pCNL65. After 2 days, the roots were transferred to CIM containing timentin, and calli were grown for 4 weeks. Calli were transferred to liquid CIM containing various antibiotics to kill the bacteria. After $\sim 4$ additional weeks, high molecular weight plant DNA was isolated and subjected to DNA gel blot analysis, as described in Methods.

(A) gusA gene probe. The upper arrow indicates the position of migration of plant high molecular weight DNA. The lower arrow indicates the position of migration of bacterial chromosomal DNA.

(B) Probe from the T-DNA binary vector replicon.

(C) Phenylalanine ammonia-lyase gene probe. gram indicated that this difference was approximately fivefold (data not shown). This result demonstrates that the extent to which the T-DNA integrated into the DNA of ecotypes $\mathrm{Aa}-\mathrm{O}$ and $\mathrm{UE}-1$ differed.

Even though we killed Agrobacterium cells with a combination of antibiotics before DNA isolation, it was important to show that the different signal intensities did not result from bacterial pCNL65 DNA contamination of the isolated Arabidopsis DNA. Therefore, we washed the gusA gene probe from the membrane and rehybridized the membrane with a 2.3-kb Notl-Bglll DNA fragment located outside of the left T-DNA border (Frisch et al., 1995). We did not detect a hybridization signal in any Arabidopsis DNA lane (Figure 6B). This result indicates that the hybridization that we observed using the gus $A$ gene probe did not result from contaminating bacterial DNA. Finally, we washed the 2.3-kb hybridization probe from the membrane and rehybridized the membrane with a phenylalanine ammonia-lyase gene probe to show that we had transferred equal amounts of Arabidopsis DNA to each lane of the membrane. Figure $6 \mathrm{C}$ shows that each lane contained an approximately equal amount of DNA.

\section{Sensitivity of Ecotypes Aa-0 and UE-1 to Ionizing Radiation}

DNA-damaging agents, especially ionizing radiation, can cause double-strand or single-strand breaks in plant chromosomes. Chromosome breaks can be repaired imprecisely in plants when a nonhomologous recombination mechanism is used. Because T-DNA is suspected to be integrated into the plant genome through an illegitimate recombination process (Matsumoto et al., 1990; Gheysen et al., 1991; Mayerhofer et al., 1991; Ohba et al., 1995), we investigated the sensitivity of ecotypes $\mathrm{Aa}-\mathrm{O}$ and $\mathrm{UE}-1$ to $\gamma$ radiation. Our rationale for this experiment was that this sensitivity may reflect the ability of the plant to integrate T-DNA into the plant genome.

We determined the sensitivity of the two ecotypes to $\gamma$ radiation by using two assays. Initially, we exposed 4-day-old Aa- 0 and UE-1 seedlings, which had only two expanded cotyledons, to different amounts of $\gamma$ radiation, after which we incubated the plants for an additional 12 days (Davies et al., 1994). Figure 7A shows that increasing doses of $\gamma$ radiation inhibited the formation of the first and second rosette leaves. At $5 \mathrm{krad}$, both ecotypes produced first and second rosette leaves, but these leaves were much smaller than those in unexposed plants. At $10 \mathrm{krad}, 100 \%$ of the Aa-0 seedlings still produced two small rosette leaves, whereas more than half of the UE-1 seedlings were so severely damaged that no true leaves developed. At $30 \mathrm{krad}$, neither ecotype produced true leaves. By using this test, ecotype UE-1 plants were found to be at least two to four times more sensitive to $\gamma$ radiation than were Aa-0 plants.

Using another test (modified from Harlow et al., 1994), we first irradiated imbibed seeds of the two ecotypes, germinated them on solidified medium, and determined the percentage of 

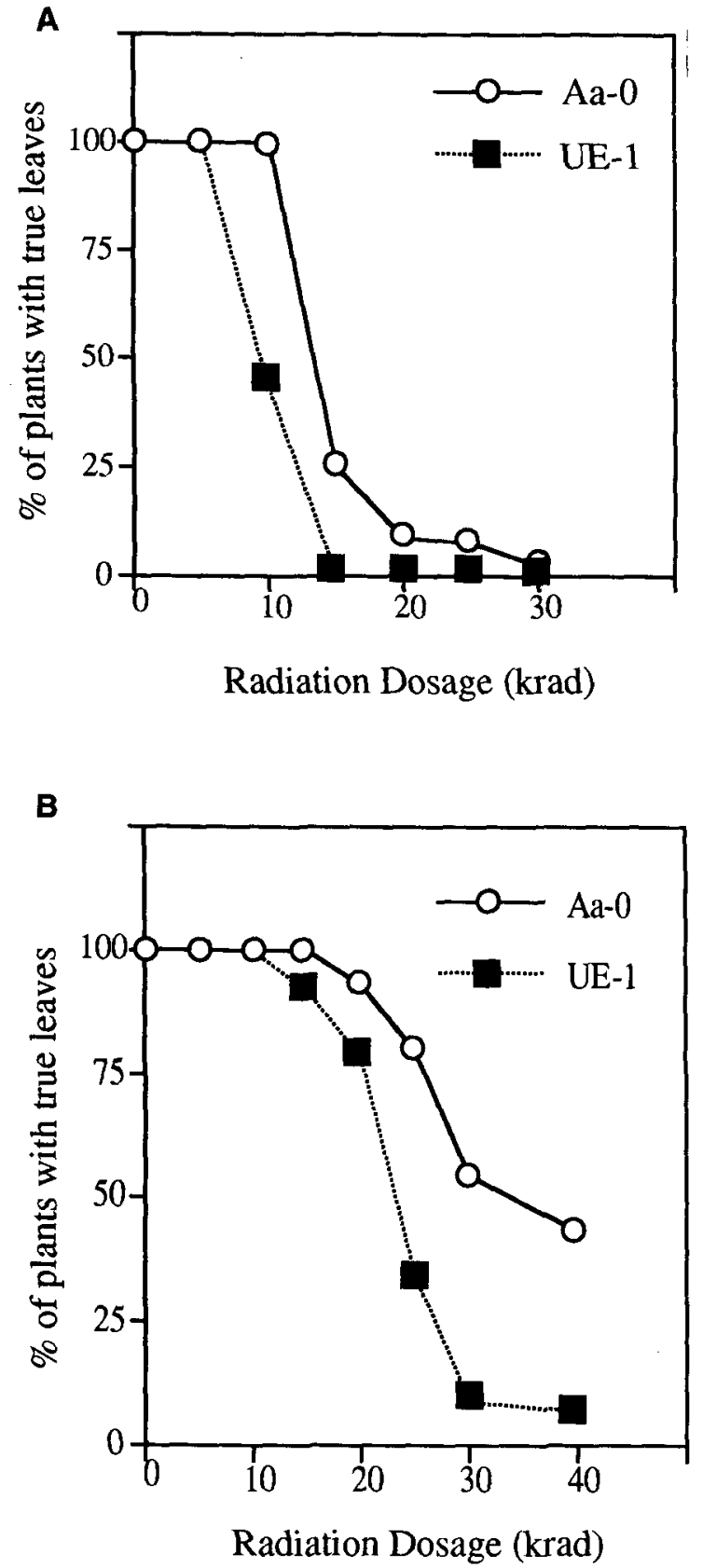

Figure 7. Sensitivity of Arabidopsis Seedlings to $\gamma$ Radiation.

(A) Four-day-old sterile seedlings of Arabidopsis ecotypes Aa-0 and UE- 1 were exposed to various amounts of $\gamma$ radiation. After 12 days the percentage of plants that developed rosette leaves was determined.

(B) Imbibed seeds of Arabidopsis ecotypes Aa-0 and UE-1 were exposed to various amounts of $y$ radiation. After 2 days of cold treatment, the seeds were moved to an incubator. After an additional 12 days, the percentage of plants that developed first and second true leaves and roots was determined. plants that produced two true leaves as well as roots. Figure $7 \mathrm{~B}$ shows that when this assay was used, seeds of ecotype UE-1 plants were three to five times more sensitive to $\gamma$ radiation than were seeds of ecotype Aa-0 plants.

\section{Genetic Basis for Differences in Susceptibility to Crown Gall Tumorigenesis and Other Stable Transformation Phenotypes}

To determine whether susceptibility to tumorigenesis is a heritable trait in Arabidopsis, we crossed ecotypes Aa-0 and UE-1 and determined the pattern of susceptibility to tumorigenesis in subsequent generations. Figure $1 \mathrm{~A}$ shows that susceptibility of inoculated root segments to tumorigenesis in the $F_{1}$ generation is a dominant characteristic. These results were verified by using a flower bolt inoculation assay (data not shown). We next determined the pattern of segregation of susceptibility to tumorigenesis in the $F_{2}$ generation. To do this, we used a semiquantitative flower bolt inoculation assay in which we measured the weight of bolt segments surrounding the inoculation site 30 days after infection. As shown in Figures 1B and 8, inoculation of flower bolts of ecotype $\mathrm{Aa}-0$ plants usually resulted in the development of tumors. Most of these tumors were large, weighing $>31 \mathrm{mg}$. Inoculation of flower bolts of ecotype UE-1 plants generally resulted in a wound response with small tumors, with most tissue segments weighing $<15$ to $20 \mathrm{mg}$. Figure $8 \mathrm{~A}$ shows the results of testing individual $F_{2}$ progeny (examples of small, intermediate, and large tumors are shown in Figure $8 \mathrm{~B}$ ). Among the $F_{2}$ segregants, approximately one-quarter of the tumors were small ( 37 of 120 [30.8\%] of the tumors weighed $<10 \mathrm{mg}$ ); approximately one-quarter of the tumors were large (27 of 120 [22.5\%] of the tumors weighed $>31 \mathrm{mg}$ ); and approximately one-half of the tumors (56 of 120 [46.7\%]) were of intermediate size. This approximate 1:2:1 segregation ratio $\left(x^{2}=3.82 ; P>0.1\right)$ suggests that susceptibility to tumorigenesis is a semidominant trait and apparently contradicts the root segment inoculation assay results (Figure 1A) that indicate that susceptibility is completely dominant. Using this stem inoculation assay, we ascribe this incomplete dominance to physiological and/or environmental effects upon tumorigenesis. Alternatively, the results could indicate segregation of multiple loci that may modify the phenotype that we monitored.

In an attempt to distinguish between these possibilities, we used a different assay to determine the heritability of another stable phenotype, kanamycin resistance. We inoculated a large number of root bundle segments from individual plants with Agrobacterium strain GV3101(pBISN1) and selected stable transformants on CIM containing kanamycin. We then calculated the percentage of root bundles from each plant that generated kanamycin-resistant calli. This percentage was 21 to $40 \%$ for the recalcitrant ecotype UE- 1 and $>81 \%$ for the susceptible ecotype Aa-0 (data not shown). More than $81 \%$ of the bundles of root segments of the $F_{1}$ 
A

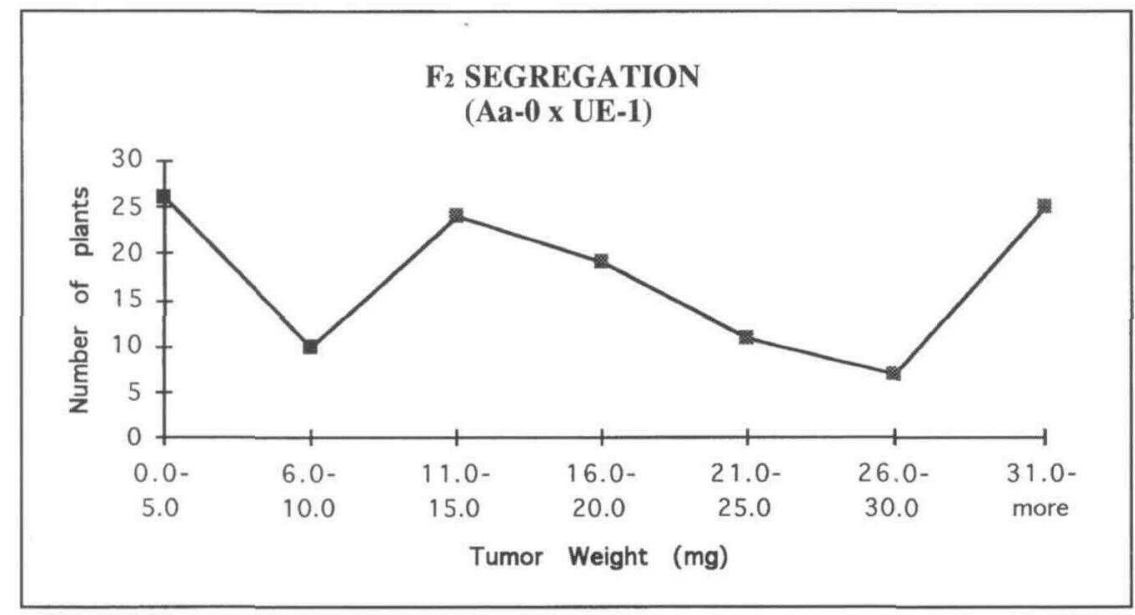

B

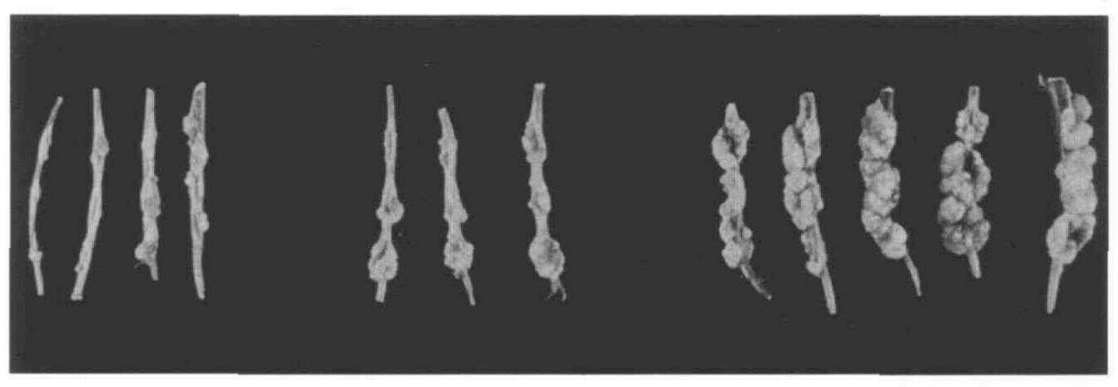

Figure 8. Segregation of the Tumorigenesis Susceptibility Phenotype among the $F_{2}$ Progeny of a Cross between Aa-0 and UE-1.

$F_{2}$ progeny of a cross between Arabidopsis ecotypes Aa-0 and UE-1 were inoculated on the flower bolt with Agrobacterium strain A208. After 4 weeks, the tumors were excised and their weights were determined.

(A) Distribution of tumor weights.

(B) Small, medium, and large tumors are shown.

progeny were kanamycin resistant, indicating that the inheritance of this trait is completely dominant (data not shown). Among the $63 \mathrm{~F}_{2}$ progeny analyzed, 45 plants $(71.4 \%)$ had root bundles that were highly kanamycin resistant $(>51 \%$ of the root bundles from each plant were kanamycin resistant), whereas 18 plants $(28.6 \%)$ had root bundles that were mostly kanamycin susceptible ( $<40 \%$ of the root bundles from each plant were kanamycin resistant). Thus, the ability to be transformed to kanamycin resistance segregates $\sim 3: 1$ $\left(\chi^{2}=0.34 ; P>0.5\right)$.

Taken together, these data indicate that susceptibility to crown gall tumorigenesis and the ability to be transformed to kanamycin resistance are heritable traits. The data further suggest that a single major contributing locus determines the inheritance of these traits. Based on the quantitative nature of this trait, however, we cannot rule out the possible influence of other loci on these phenotypes.

\section{Screening of Additional Arabidopsis Ecotypes by Using a Different Tumorigenesis Assay}

The amenability to genetic analysis of Agrobacteriuminduced tumorigenesis suggests that it may be possible genetically to dissect this complex phenomenon to its distinct genetic components. Furthermore, our initial screening indicated that there was considerable ecotype variability in response to Agrobacterium-induced tumorigenesis. To explore this variability to a greater extent, we examined the tumorigenesis response of a total of 36 different Arabidopsis ecotypes, including $\mathrm{Aa}-\mathrm{O}$ and $\mathrm{UE}-1$, using a new in vitro root bundle tumorigenesis assay. We infected sterile root segments with Agrobacterium without preincubation of the roots on CIM. After cocultivation for 2 days, we transferred small bundles of roots, rather than spreading individual root segments, to Murashige and Skoog (MS; Murashige and 
Skoog, 1962) basal medium containing timentin. We found that this protocol was more effective for testing a large number of samples and avoided potential preincubation hormone effects upon subsequent tumorigenesis. We classified the response of these ecotypes into four categories: hypersusceptible, intermediate, recalcitrant, and no response. Table 1 shows that a wide variation in ecotype susceptibility to Agrobacterium exists. Ecotypes Aa-0, Be-0, Moskau (Ms-0), Weiningen (Wei-0), and Wassilewskija (WS) showed a very strong response to Agrobacterium strain A208; tumors from these ecotypes developed large green teratomas. Most of the ecotypes examined showed an intermediate response. We scored ecotypes Antwerpen (An-1), Angleur (Ang-0), Bologna (Bl-1), Blanes/Gerona (Bla-2), Calver (Cal-0), Dijon-G, Estland (Est), Petergof, and M7323S as recalcitrant to tumorigenesis because these ecotypes showed almost no tumorigenesis response to Agrobacterium strain A208. Ecotype UE-1 still showed small yellow tumors lacking teratomas.

Using this new inoculation assay, we infected roots of some of the more recalcitrant ecotypes and ecotype Aa-0 with Agrobacterium GV3101(pBISN1). Figure 9A shows the results of transient GUS activity assays conducted with root segments 2 days after infection of various Arabidopsis ecotypes by Agrobacterium harboring pBISN1. Ecotypes $\mathrm{Aa}-0$, Est, and UE-1 showed a high level of GUS activity, whereas ecotypes $\mathrm{Bl}-1$ and Petergof showed only a low level.

Figure 9B shows the results of GUS activity assays conducted with calli (not selected for kanamycin resistance or tumorigenesis) derived from these same inoculated Arabidopsis ecotypes. Ecotype Aa-0 showed a high level of stable GUS expression. Ecotype Est showed a lower level of stable GUS activity. Ecotypes BI-1, Cal-0, Dijon-G, and UE-1, however, showed a very low level of stable GUS activity.

Table 1. Tumorigenesis of Arabidopsis Root Segments Inoculated with Agrobacterium Strain A208

\begin{tabular}{ll}
\hline Tumorigenesis Phenotype $^{\mathrm{a}}$ & Ecotypes \\
\hline+++ & Aa-0, Be-0, Ms-0, Wei-0, Ws, and \\
& M7884S \\
& Bla-6, Bla-10, Ber, Co-1, Co-2, \\
& Col, Col-0, C24, Cvi-0, \\
& Enkheim-D, Enkheim-T, Hodja, \\
& Ler, Li-0, Lip, No-0, Oy-0, RLD, \\
& and Shahdara \\
& Ag-0 and UE-1 \\
+ & An-1, Bl-1, Est, Petergof, and \\
$+1-$ & M7323S \\
- & Ang-0, Bla-2, Cal-0, and Dijon-G \\
\hline
\end{tabular}

$\mathrm{a}+++$, large green teratomas; ++ , medium yellow calli without teratomas; + , small yellow calli; -, no response. Infection of all ecotypes with the Ti-plasmidless Agrobacterium strain A136 resulted in no tumor formation.

b Shooting response rather than formation of teratomas.
A

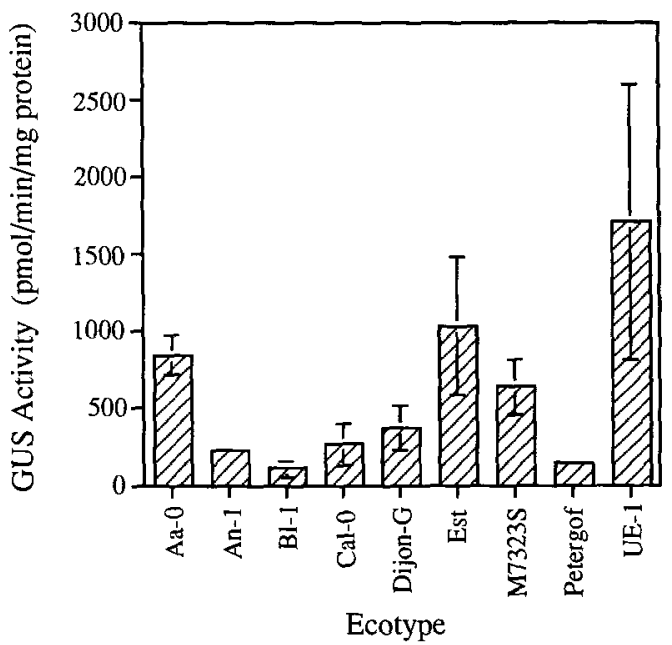

B

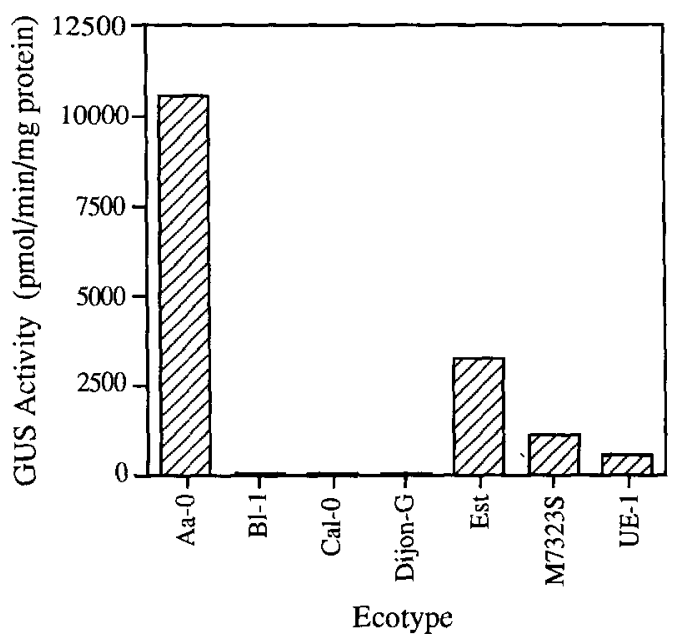

Figure 9. Quantitative Determination of Transient and Stable GUS Expression in Arabidopsis Root Segments.

Sterile root bundles of Arabidopsis ecotypes Aa-0, An-1, Bi-1, Cal-0, Dijon-G, Est, M7323S, Petergof, and UE-1 were infected with Agrobacterium strain GV3101 harboring the plasmid pBISN1.

(A) GUS activity was determined in the root segments after 2 days by using a quantitative MUG fluorometric assay, as described in Methods.

(B) GUS activity was determined in calli derived from root segments grown on CIM for 4 weeks by using a quantitative MUG fluorometric assay, as described in Methods.

The relative abilities of these ecotypes to display stable GUS activity were reflected by their kanamycin resistance after transformation. Both ecotypes $\mathrm{Aa}-\mathrm{O}$ and Est generated kanamycin-resistant calli, whereas ecotypes Bl-1, Cal-0, Dijon-G, and UE-1 did not (data not shown). 
The finding that ecotypes $\mathrm{Bl}-1, \mathrm{Cal}-0$, and Dijon-G could demonstrate neither transient nor stable GUS activity suggests that for these ecotypes, the transformation process is blocked at an early stage of T-DNA transfer or expression.

\section{Binding of Agrobacterium to Roots of Susceptible and Recalcitrant Arabidopsis Ecotypes}

Because a deficiency in tumorigenesis at an early stage of T-DNA transfer could result from lack of bacterial binding to plant cells, we investigated the ability of Agrobacterium to attach to root segments from several susceptible and recalcitrant Arabidopsis ecotypes. Figures $10 \mathrm{~A}$ and 10B, respectively, show that when we examined the surface of infected roots of ecotypes Aa- 0 and WS (two susceptible ecotypes) 2 days after infection, we could detect large numbers of bacteria adhering to the surface of the root along the epidermis, the root hairs, and the mucigel layer surrounding the root. In many places, the bacteria formed a layer completely covering the surface of the root. We also observed large aggregates of bacteria on the cut ends of the root segments (data not shown). However, when we incubated root segments of ecotypes $\mathrm{Bl}-1$ and Petergof (two recalcitrant ecotypes) with Agrobacterium, we observed only a few bacteria adhering to the root epidermis (Figures $10 \mathrm{C}$ and $10 \mathrm{D}$, respectively). We detected some bacteria attached to the cut end of the segments, but they were sparsely distributed compared with the bacteria found on the wounded ends of root segments of ecotypes Aa-O and WS (data not shown). When we incubated root segments of any of these four ecotypes with a nonattaching mutant of Agrobacterium (C58::B123; Matthysse, 1994), we did not observe binding to the epidermis or to the cut ends of the root segments (data not shown).

The reduced bacterial binding to ecotypes $\mathrm{Bl}-1$ and Petergof could result from a lack of sites on the plant surface to which the bacteria could bind or to the failure of the plant to induce bacterial cellulose synthesis. Thus, it was important to examine the ability of the wounded plants to induce bacterial cellulose synthesis. When we incubated wild-type Agrobacterium C58 separately in MS medium in a flask outside of dialysis tubing containing cut plants of each of the four ecotypes, the bacteria of all four ecotypes formed strings or threads visible to the unaided eye (data not
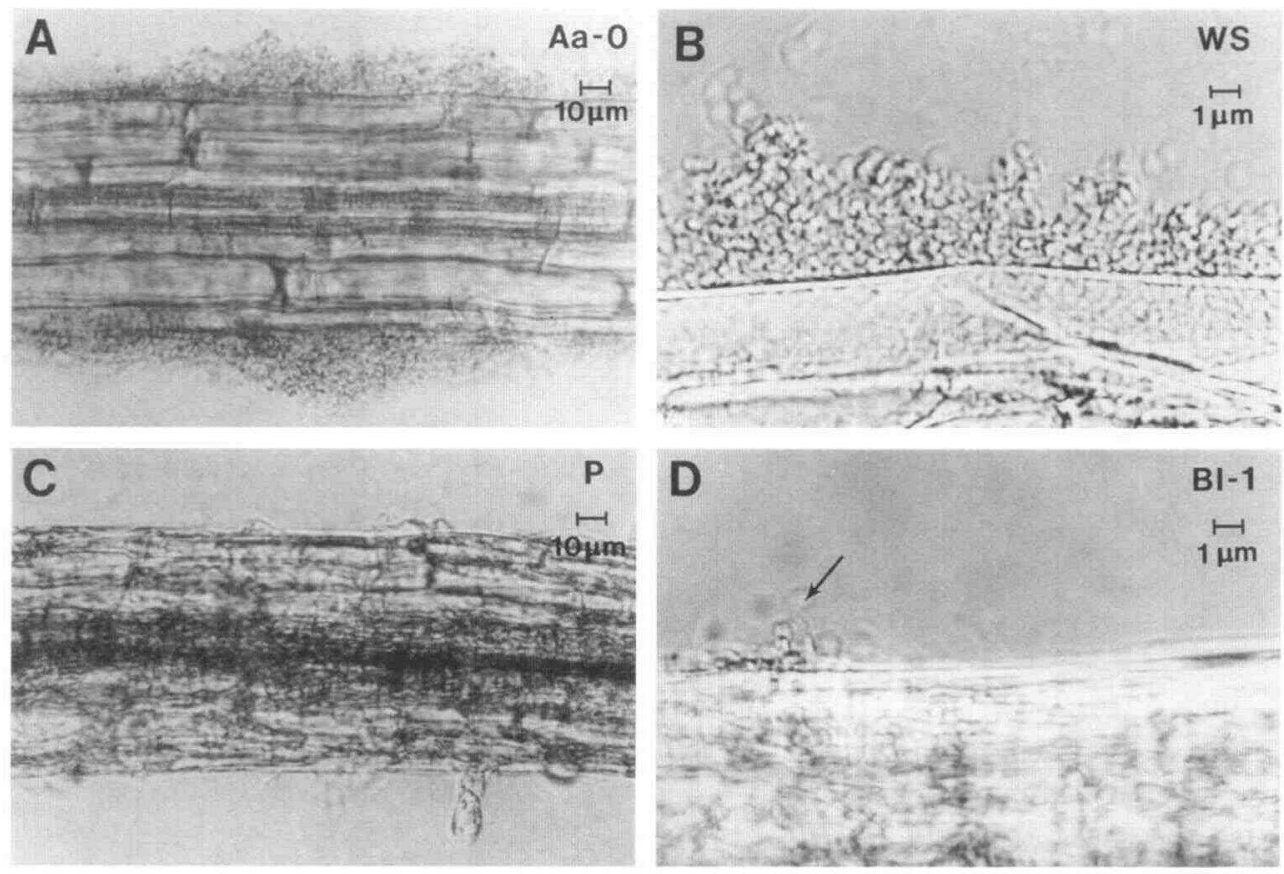

Figure 10. Adhesion of Agrobacterium Strain C58 to Roots of Arabidopsis Ecotypes.

Agrobacteria were incubated with roots of various Arabidopsis ecotypes, as described in Methods, and visualized using a light microscope.

(A) Ecotype Aa-0.

(B) Ecotype WS.

(C) Ecotype Petergof (P).

(D) Ecotype Bl-1.

Note the large number of bacteria covering the epidermis of Aa-0 and WS in (A) and (B). Very few bacteria can be seen on the surface of roots of ecotypes Petergof and $\mathrm{Bl}-1$ in (C) and (D). An occasional cluster of a few bacteria was observed on the roots of $\mathrm{Bl}-1$ (arrow in [D]). 
shown). These threads could be digested by cellulase but not by pronase (data not shown). A cellulose-minus mutant of C58 (C58::1; Matthysse et al., 1995) did not produce visible threads when incubated under these conditions with the ecotype Petergof (data not shown). Thus, we cannot attribute the lack of attachment of wild-type bacteria to the roots of ecotypes $\mathrm{Bl}-1$ and Petergof to a failure of the wounded plants to induce cellulose synthesis.

\section{DISCUSSION}

In this article, we show that there is considerable variation in susceptibility to crown gall tumorigenesis among a large number of Arabidopsis ecotypes. We further show that susceptibility is a heritable trait. Recalcitrance to tumorigenesis may result from a number of causes, including defects in binding of Agrobacterium to plant cells and deficiencies in integration of T-DNA into the plant genome.

To determine the extent of variability in susceptibility to crown gall tumorigenesis, we initially inoculated root segments of 11 Arabidopsis ecotypes with four Agrobacterium strains. Among the three tumorigenic strains tested, inoculation with Agrobacterium strain A208 (containing the nopalinetype Ti plasmid pTiT37) resulted in the highest percentage of individual root segments developing tumors. These tumors eventually developed into teratomas that produced nopaline (data not shown). Agrobacterium strain A348 (harboring the octopine-type Ti plasmid pTiA6) also incited tumors on a high percentage of root segments; however, these unorganized tumors were often difficult to distinguish from callus growth resulting from the inoculation of root segments with the avirulent Agrobacterium strain A136. Somewhat surprisingly, inoculation of Arabidopsis root segments with Agrobacterium strain A281 (harboring the supervirulent Ti plasmid pTiBo542) did not result in efficient tumorigenesis. Although Agrobacterium strains harboring $\mathrm{pTiBo542}$ may be highly tumorigenic on some plant species, they are not necessarily supervirulent on all species (Hood et al., 1987). Arabidopsis is apparently a species not easily transformed by Agrobacterium strain A281.

From among the 11 Arabidopsis ecotypes initially screened, we selected the ecotype $\mathrm{Aa}-\mathrm{O}$ as the most susceptible and the ecotype UE-1 as the most recalcitrant to crown gall tumorigenesis. Using this root inoculation assay, however, required a hormone preincubation of the root segments of all ecotypes, including $\mathrm{Aa}-\mathrm{O}$, for tumor formation. We determined that the optimum preincubation condition was 1 day on CIM. Incubation for longer periods resulted in nontumorous callus growth on the roots of most ecotypes. These calli were difficult to distinguish from unorganized tumors incited by Agrobacterium A348. We did not encounter these problems, however, when scoring tumorigenesis by the teratoma-inducing strain Agrobacterium A208. Others have also determined that preincubation of explants on hormonecontaining medium is important for efficient transformation of Arabidopsis to generate transgenic plants (Lloyd et al., 1986; Schmidt and Wilmitzer, 1988; Valvekens et al., 1988; Chaudhury and Signer, 1989; Sangwan et al., 1991, 1992; Akama et al., 1992; Clarke et al., 1992; Mandal et al., 1993).

In our later studies, we used a modified root inoculation assay. In this assay, we inoculated bundles of $\sim 10$ root segments; we did not spread individual root segments on the agar. This assay is easier to perform than was our previous assay and does not require preincubation of root segments on CIM before inoculation with Agrobacterium. The assay is also more sensitive, perhaps because it measures the cumulative effect of tumorigenesis upon many infected explants simultaneously rather than tumorigenesis on each individual root segment. We used this modified assay to screen 36 Arabidopsis ecotypes. Among these, five ecotypes (Be-0, Ms- 0 , Wei-0, WS, and M7884S) gave responses as strong as did ecotype Aa-0, and 10 ecotypes (Ag-0, An-1, Ang-0, Bl-1, Bla-2, Cal-0, Dijon-G, Est, Petergof, and M7323S) gave responses at least as weak or weaker than did ecotype UE-1 (Table 1).

To determine specific causes for recalcitrance to crown gall tumorigenesis, we examined ecotypes $\mathrm{Aa}-0$ and UE- 1 in detail. Recalcitrance (or a total lack of response to infection) could result from a number of causes. These include defects in the ability of plant extracts to induce Agrobacterium vir genes, defects in the ability of the bacteria to bind to the plant cell, deficiencies in the ability of the bacteria to transfer T-DNA to the plant cell, defects in T-DNA nuclear targeting or integration into the plant genome, a lack of ability to express T-DNA-encoded genes, or the plant's lack of response to the phytohormones whose synthesis is directed by T-DNA-encoded genes.

Hormone-activated and dividing cells are more prone to transformation than are nondividing cells (Bergmann and Stomp, 1992; Sangwan et al., 1992), and metabolically active plant cells may produce molecules that induce the $\mathrm{Ti}$ plasmid-encoded vir genes (Stachel et al., 1985). Therefore, we first investigated whether any gross differences existed between ecotypes Aa-0 and UE- 1 with regard to the biosynthesis of several classes of macromolecules or their ability to produce chemicals that could induce vir genes. We saw little difference between these two ecotypes in the rates of DNA and protein biosynthesis as measured by ${ }^{3} \mathrm{H}$-thymidine and ${ }^{14} \mathrm{C}$-amino acid incorporation into macromolecules, respectively. In addition, there was little difference in the ability of exudates from roots of either of these ecotypes to induce a virH::/acZ fusion gene in Agrobacterium strain At41. Because crown gall tumorigenesis results from a plant's response to auxins and cytokinins whose biosynthetic genes are encoded by the T-DNA (Gelvin, 1990), we examined the response of ecotypes Aa-0 and UE- 1 to these hormones by using a primary root growth inhibition assay. The similarity in sensitivity of these two ecotypes to externally applied hormones suggests that the differences in their susceptibility to crown gall tumorigenesis do not result from differences in their responses to these phytohormones. Therefore, we 
conclude that the difference in susceptibility to tumorigenesis does not result from major metabolic differences between these two ecotypes.

To determine whether the recalcitrance of ecotype UE-1 to crown gall tumorigenesis resulted from the inability of the T-DNA to transfer to the plant nucleus (either because of a deficiency in bacterial binding to the plant cell or a defect in T-DNA transfer to the plant or T-DNA nuclear transport), we conducted "transient transformation" assays by monitoring the expression of a T-DNA-localized gusA-intron gene in inoculated Arabidopsis root segments. We initially utilized a gusA-intron gene under the control of a CaMV $35 \mathrm{~S}$ promoter (Figure 2), although in later experiments we used a more sensitive assay in which the gusA-intron gene was regulated by a stronger super promoter ( $\mathrm{Ni}$ et al., 1995). Using this latter assay, we could detect GUS activity as early as 2 or 3 days after infection, and infection of ecotype UE-1 resulted in approximately twice the GUS activity as infection of ecotype Aa-O (Figures 5 and 9A). Thus, the ecotype UE-1 is at least as competent as is the ecotype Aa- 0 in its ability to transfer T-DNA to the nucleus and convert the singlestranded T-strand to a double-stranded transcription competent form. GUS expression in ecotype UE-1 was highly transient, however, whereas stable GUS expression was detected in ecotype Aa-0 (Figures 4, 5, and 9B). The inefficient transformation of ecotype UE-1 to kanamycin resistance (Figure 3) further reflects the difficulty in stabilizing T-DNAencoded traits in this ecotype.

The ability to transform ecotype UE- 1 transiently but not stably suggested that in this ecotype, T-DNA integration may be deficient. We tested this hypothesis directly by investigating the efficiency of T-DNA integration into the genomes of ecotypes Aa-O and UE-1. We found that in unselected tissue derived from Agrobacterium-infected roots, approximately five times more T-DNA was integrated per microgram of high molecular weight plant DNA in ecotype Aa-0 than in ecotype UE-1 (Figure 6A). Control experiments (Figure $6 \mathrm{~B}$ ) indicated that the T-DNA signal that we detected on DNA blots did not derive from contaminating Agrobacterium cells. This is the definitive demonstration of natural variability in Agrobacterium-mediated plant transformation resulting from a deficiency in T-DNA integration. Experiments in our laboratory have suggested that the difficulty in transforming maize by using Agrobacterium results from a deficiency in T-DNA integration in but not T-DNA transfer to this species (Narasimhulu et al., 1996).

In accordance with the deficiency in T-DNA integration in ecotype UE-1, we found that this ecotype is two to five times more sensitive to $\gamma$ radiation than is ecotype Aa-0 (Figure 7). This radiation sensitivity may reflect a defect in single- and/or double-strand DNA break repair. Interestingly, such repair processes may play a role in T-DNA integration via illegitimate recombination (Matsumoto et al., 1990; Gheysen et al., 1991; Mayerhofer et al., 1991; Ohba et al., 1995). Recently, Sonti et al. (1995) reported that two Arabidopsis mutants, uvh1 (UV hypersensitive) and rad5 ( $\gamma$ radi- ation hypersensitive), can both be transformed transiently (transient GUS expression) but not stably to kanamycin resistance or to tumors. The authors concluded that these Arabidopsis mutants were deficient in T-DNA integration. We have since repeated these experiments using the same mutants but with our Agrobacterium strains and assays. We have found that the uvh1 mutant can easily be transformed to yield crown gall tumors and that the efficiency of T-DNA integration per microgram of plant DNA is approximately the same in the mutant as in the wild-type plant. In addition, we determined that the rad5 mutant is deficient in its ability to be transformed to crown gall tumors and to integrate T-DNA. This mutant, however, is equally deficient in its ability to express GUS activity transiently. Thus, the block to stable transformation in the mutant rad5 must occur at some step before T-DNA integration (J. Nam and S.B. Gelvin, manuscript in preparation).

Genetic analysis of crosses between ecotypes $\mathrm{Aa}-\mathrm{O}$ and UE-1 indicated that in the $F_{1}$ generation, susceptibility to crown gall tumorigenesis is a dominant trait (Figure 1A). Analysis of the $F_{2}$ progeny suggested, however, that this susceptibility may be semidominant: the ability to be transformed to small, medium, and large tumors segregated 1:2:1 (Figure $8 A)$. However, when we examined the ability of the $F_{1}$ and $F_{2}$ progeny to be transformed to kanamycin resistance, this trait segregated as though it were attributable to one major dominant locus. We suggest that the incomplete dominance regarding susceptibility to tumorigenesis results from physiological and/or environmental factors that affected the plants during the tumor growth period. We cannot, however, rule out the possibility that there are additional segregating loci that contribute to tumorigenesis. Bailey et al. (1994) and Mauro et al. (1995) showed that susceptibility to crown gall tumorigenesis among soybean cultivars is also a quantitative trait.

After we had conducted extensive analyses on ecotypes $\mathrm{Aa}-0$ and UE-1, we rescreened a larger collection of Arabidopsis ecotypes by using the more rapid and sensitive root bundle tumorigenesis assay. We identified a large number of ecotypes that were highly recalcitrant to crown gall tumorigenesis (Table 1). Several of these ecotypes, including An-1, $\mathrm{BI}-1$, Cal-0, Dijon-G, and Petergof, were recalcitrant to transient as well as stable transformation, as determined by quantitative GUS assays (Figure 9). These ecotypes were thus likely to be blocked in an early step in the tumorigenesis process. Therefore, we examined the ability of Agrobacterium to bind to root segments of two of these recalcitrant ecotypes, Bl-1 and Petergof. Binding of bacterial cells to root surfaces was highly attenuated compared with binding to the surfaces of the susceptible ecotypes Aa-0 and WS (Figure 10). Binding of Agrobacterium to host cells is believed to be required for the transfer of T-DNA and subsequent tumor formation. All nonattaching mutants of the bacteria that have been isolated are avirulent (Douglas et al., 1982; Cangelosi et al., 1987; Matthysse, 1987; Thomashow et al., 1987). The identity of the receptor on the plant surface to which the bacteria bind is not known. Experiments in which the plant 
surface was treated with various enzymes before bacterial attachment and the ability of various enzymes and extracts to inhibit bacterial attachment suggest that a protein on the plant surface is required for bacterial binding (Neff and Binns, 1985; Gurliltz et al., 1987).

Because recalcitrance to crown gall tumorigenesis in the ecotype UE-1 appeared to segregate as a single major contributing locus, we initiated more sophisticated genetic analyses in an attempt to isolate genes involved in transformation using a positional cloning approach. Concurrently, we have explored the possibilities of using a T-DNA-tagged Arabidopsis library (Feldmann and Marks, 1987; Feldmann, 1991) to identify mutants that are recalcitrant to tumorigenesis. We have identified 10 to 15 such mutants that are likely blocked in different stages of the tumorigenesis process (J. Nam, M. Knue, and S.B. Gelvin, unpublished data). We are currently analyzing these tagged genes to determine the nature of plant-encoded proteins that are necessary for crown gall tumorigenesis.

\section{METHODS}

\section{Plant Growth Conditions}

Seeds of various Arabidopsis thaliana ecotypes were kind gifts of $S$. Leisner and E. Ashworth (originally from the Arabidopsis Stock Centre, Nottingham, UK, and the Arabidopsis Biological Resource Center, Ohio State University, Columbus, respectively). Seeds were surface sterilized with a solution composed of $50 \%$ commercial bleach and $0.1 \%$ SDS for $10 \mathrm{~min}$ and then rinsed five times with sterile distilled water. The seeds were germinated in Petri dishes containing Gamborg's B5 medium (GIBCO) solidified with $0.75 \%$ bactoagar (Difco). The plates were incubated initially at $4^{\circ} \mathrm{C}$ for 2 days and then for 7 days under a 16 -hr-light $/ 8$-hr-dark photoperiod at $25^{\circ} \mathrm{C}$. Seedlings were individually transferred into baby food jars containing solidified B5 medium and grown for 7 to 10 days for root culture. Alternatively, the seedlings were transferred into soil for bolt inoculation.

\section{Growth of Agrobacterium tumefaciens}

All Agrobacterium strains were grown in YEP medium (Lichtenstein and Draper, 1986) supplemented with the appropriate antibiotics (rifampicin, $10 \mu \mathrm{g} / \mathrm{mL}$; kanamycin, $100 \mu \mathrm{g} / \mathrm{mL}$ ) at $30^{\circ} \mathrm{C}$. Overnight bacterial cultures were washed with $0.9 \% \mathrm{NaCl}$ and resuspended in $0.9 \%$ $\mathrm{NaCl}$ at $2 \times 10^{9}$ colony-forming units per $\mathrm{mL}$ for in vitro root inoculation or at $2 \times 10^{11}$ colony-forming units per $\mathrm{mL}$ for bolt inoculation.

\section{In Vitro Root Inoculation and Transformation Assays}

Roots grown on the agar surface were excised, cut into small segments $(\sim 0.5 \mathrm{~cm})$ in a small amount of sterile water, and blotted onto sterile filter paper to remove excess water. For some experiments, we preincubated excised roots on callus-inducing medium (CIM; $4.32 \mathrm{~g} / \mathrm{L}$ Murashige and Skoog [MS] minimal salts [GlBCO], $0.5 \mathrm{~g} / \mathrm{L}$ Mes, $\mathrm{pH} 5.7,1 \mathrm{~mL} / \mathrm{L}$ vitamin stock solution $[0.5 \mathrm{mg} / \mathrm{mL}$ nicotinic acid, $0.5 \mathrm{mg} / \mathrm{mL}$ pyridoxine, and $0.5 \mathrm{mg} / \mathrm{mL}$ thyamine- $\mathrm{HCl}$ ], $100 \mathrm{mg} / \mathrm{L}$ myoinositol, $20 \mathrm{~g} / \mathrm{L}$ glucose, $0.5 \mathrm{mg} / \mathrm{L}$ 2,4-dichlorophenoxyacetic acid,
$0.3 \mathrm{mg} / \mathrm{L}$ kinetin, $5 \mathrm{mg} / \mathrm{L}$ indoleacetic acid, and $0.75 \%$ bactoagar) for 1 day before cutting them into segments. Dried bundles of root segments were transferred to MS basal medium $(4.32 \mathrm{~g} / \mathrm{L} \mathrm{MS} \mathrm{minimal}$ salts, $0.5 \mathrm{~g} / \mathrm{L}$ Mes, $\mathrm{pH} 5.7,1 \mathrm{~mL} / \mathrm{L}$ vitamin stock solution, $100 \mathrm{mg} / \mathrm{L}$ myoinositol, $10 \mathrm{~g} / \mathrm{L}$ sucrose, and $0.75 \%$ bactoagar), and 2 or 3 drops of the bacterial suspension were placed on them. After $10 \mathrm{~min}$, most of the bacterial solution was removed, and the bacteria and root segments were cocultivated at $25^{\circ} \mathrm{C}$ for 2 days.

For transient transformation assays, the root bundles were infected with Agrobacterium strain A208 (Sciaky et al., 1978) containing the binary vector pCNL65 (Liu et al., 1992). Alternatively, we used Agrobacterium strain GV3101 (Koncz and Schell, 1986) containing the binary vector pBISN1 (Narasimhulu et al., 1996). After various periods of time, the roots were rinsed with water, blotted on filter paper, and stained with X-gluc staining solution $\left(50 \mathrm{mM} \mathrm{NaH}_{2} \mathrm{PO}_{4}, 10 \mathrm{mM}\right.$ $\mathrm{Na}_{2}$. EDTA, $300 \mathrm{mM}$ mannitol, and $2 \mathrm{mM} \mathrm{X-gluc,} \mathrm{pH} 7.0$ ) for 1 day at $37^{\circ} \mathrm{C}$. For quantitative measurements of $\beta$-glucuronidase (GUS) activity, the roots were ground in a microcentrifuge tube containing GUS extraction buffer ( $50 \mathrm{mM} \mathrm{Na} \mathrm{HPO}_{4}, 5 \mathrm{mM}$ DTT, $1 \mathrm{mM} \mathrm{Na} 2$. EDTA, $0.1 \%$ sarcosyl, and $0.1 \%$ Triton $X-100, \mathrm{pH} 7.0$ ), and GUS specific activity was measured according to Jefferson et al. (1987).

To quantitate tumorigenesis, root bundles were infected with wildtype Agrobacterium strains. After 2 days, the root bundles were rubbed on the agar surface to remove excess bacteria and then washed with sterile water containing timentin $(100 \mu \mathrm{g} / \mathrm{mL})$. Individual root segments (initial assay) or small root bundles (5 to 10 root segments; modified assay) were transferred onto MS basal medium lacking hormones but containing timentin $(100 \mu \mathrm{g} / \mathrm{mL})$ and incubated for 4 weeks at $25^{\circ} \mathrm{C}$.

For transformation of root segments to kanamycin resistance, root bundles were inoculated with Agrobacterium strain A208 containing pCNL65 or Agrobacterium strain GV3101 containing pBISN1. After 2 days, small root bundles (or individual root segments) were transferred onto CIM containing timentin $(100 \mu \mathrm{g} / \mathrm{mL})$ and kanamycin $(50$ $\mu \mathrm{g} / \mathrm{mL}$ ). Kanamycin-resistant calli were scored after 4 weeks of incubation at $25^{\circ} \mathrm{C}$.

To determine stable GUS expression, we inoculated roots as given above and transferred the root segments after 2 days to CIM containing timentin $(100 \mu \mathrm{g} / \mathrm{mL})$ without any selection. After 4 weeks, GUS activity was assayed either by staining with $X$-gluc or by measuring GUS specific activity by using a 4 -methylumbelliferyl $\beta$-Dgalactoside (MUG) fluorometric assay, as described above.

To determine the kinetics of GUS expression, we infected root bundles, transferred the root segments after 2 days to CIM containing timentin $(100 \mu \mathrm{g} / \mathrm{mL})$, and grew calli on CIM without selection. Root bundles were assayed at various times, using a MUG fluorometric assay as described above, to measure GUS specific activity.

\section{Metabolic Rate Analysis}

Sterile roots were cut into $0.5-\mathrm{cm}$ segments (either without preincubation or after preincubation of the roots on CIM for 1 day) and incubated in $5 \mathrm{~mL}$ of liquid $\mathrm{MS}$ basal medium containing ${ }^{14} \mathrm{C}$-amino acids (2 $\mu \mathrm{Ci} / \mathrm{mL}$; Amersham) or ${ }^{3} \mathrm{H}$-thymidine $(2 \mu \mathrm{Ci} / \mathrm{mL}$; Amersham) at $25^{\circ} \mathrm{C}$. Five root segments were collected each hour and ground in a microcentrifuge tube containing hot $\left(90^{\circ} \mathrm{C}\right)$ extraction solution $(10 \%$ trichloroacetic acid [TCA] plus $1 \%$ casamino acids for ${ }^{14} \mathrm{C}$-amino acid incorporation or $10 \%$ TCA plus $1 \%$ yeast extract for ${ }^{3} \mathrm{H}$-thymidine incorporation). The solution was filtered through a glass fiber filter (Whatman), washed twice with $20 \mathrm{~mL}$ of cold $10 \%$ TCA solution, 
and air dried. The amount of incorporated isotope was determined by scintillation counting.

\section{Analysis of vir Gene Induction}

To test for vir gene induction, we incubated Agrobacterium strain At41 (containing a virH::lacZ fusion; strain $m \times 219$ of Stachel and Nester [1986]) in a small Petri dish containing $5 \mathrm{~mL}$ of MS basal medium and 25 cut root segments. After $24 \mathrm{hr}$ of cocultivation at $25^{\circ} \mathrm{C}$ with gentle shaking, the bacterial cells were harvested and washed in $Z$ buffer (Miller, 1972), and virH gene activity was determined by monitoring $\beta$-galactosidase activity according to Miller (1972).

\section{Hormone Sensitivity Assays}

Sterilized seeds of each Arabidopsis ecotype were germinated on agar plates containing Gamborg's B5 medium. One-week-old seedlings were transferred to new Gamborg's B5 medium agar plates containing various concentrations of hormones, and the initial primary root length was marked. The plates were sealed with Parafilm (American National Can, Neenah, Wl) and placed in a vertical position in a growth chamber at $25^{\circ} \mathrm{C}$. After 2 days, we measured additional primary root growth.

\section{Bolt Inoculation Assay}

The primary inflorescence shoot of Arabidopsis plants grown in soil at $25^{\circ} \mathrm{C}$ was wounded by stabbing with a needle when the bolt had reached a height of 4 to $5 \mathrm{~cm}$. The plant exudate from the wound was removed by briefly touching the sites with an AccuWipe (Fort Howard, Green Bay, WI). We then inoculated $3 \mu \mathrm{L}$ of a highly concentrated bacterial suspension ( $2 \times 10^{11}$ colony-forming units per $\mathrm{mL}$ ) into the wound. The plants were covered with a plastic bag for 3 days to keep the humidity high and to allow efficient infiltration of the bacterial suspension. After 4 weeks, the response was scored by weighing the tumors.

\section{Sensitivity to lonizing Radiation}

We exposed 4-day-old sterile Arabidopsis seedlings (grown in solidified Gamborg's B5 medium, 40 plants per plate) to different amounts of $\gamma$ radiation $\left({ }^{60} \mathrm{Co}, 3522 \mathrm{rad} / \mathrm{min}\right.$; Nordion $\gamma$-Cell 220; Kanata, Ontario, Canada) and then incubated them for 12 days in a growth chamber $\left(16 \mathrm{hr}\right.$ of light and $8 \mathrm{hr}$ of dark at $25^{\circ} \mathrm{C}$ ). Symptoms of severe radiation damage were scored by determining the percentage of plants that developed first and second true leaves. Alternatively, imbibed sterile seeds were exposed as described above and immediately sowed on solidified Gamborg's B5 medium (rather than in soil; Harlow et al., 1994). By germinating the seeds in an agar medium, we observed the exact germination frequency and root development. After cold treatment of the plates for 2 days at $4^{\circ} \mathrm{C}$, we incubated the plates at $25^{\circ} \mathrm{C}$ for an additional 12 days. Because ionizing radiation inhibited root as well as leaf development, we scored symptoms of severe radiation damage by determing the percentage of plants that developed the first and second true leaves as well as roots.

\section{Genomic DNA Blot Analysis}

Sterile root bundles were inoculated with Agrobacterium strain A208(pCNL65), and after 2 days cocultivation, calli were grown for $\sim 4$ weeks on $\mathrm{CIM}$ containing $100 \mu \mathrm{g} / \mathrm{mL}$ timentin. The calli were transferred to liquid CIM, and a cell suspension was generated. This suspension was maintained for $\sim 4$ weeks, during which time we rotated through the medium several different antibiotics (timentin, 100 $\mu \mathrm{g} / \mathrm{mL}$; carbenicillin, $500 \mu \mathrm{g} / \mathrm{mL}$; vancomycin, $500 \mu \mathrm{g} / \mathrm{mL}$; and cefotaxime, $500 \mu \mathrm{g} / \mathrm{mL}$ ) to prevent bacterial growth. High molecular weight DNA was isolated by the method of Dellaporta (1984), the undigested DNA was subjected to electrophoresis through a $0.6 \%$ agarose gel, and after denaturation and neutralization, the DNA was transferred to a nylon membrane (Nitran; Schleicher \& Schuell). Hybridization probes were labeled with ${ }^{32} \mathrm{P}$-dCTP by using an Amersham Multiprime DNA labeling system. Hybridization was performed in a solution containing $360 \mathrm{mM} \mathrm{NaCl}, 20 \mathrm{mM}$ Tris- $\mathrm{HCl}, \mathrm{pH} 7.0,2 \mathrm{mM}$ $\mathrm{Na}_{2} \cdot$ EDTA, $1.0 \%$ SDS, $0.5 \%$ skim milk, and $100 \mu \mathrm{g} / \mathrm{mL}$ denatured sperm DNA for $16 \mathrm{hr}$ at $65^{\circ} \mathrm{C}$. The membrane was washed in $2 \times$ SSC $(1 \times$ SSC is $0.15 \mathrm{M} \mathrm{NaCl}, 0.015 \mathrm{M}$ sodium citrate) and $1.0 \%$ SDS for $30 \mathrm{~min}$ at $65^{\circ} \mathrm{C}$ and in $1 \times$ SSC and $1.0 \%$ SDS for $30 \mathrm{~min}$ at $65^{\circ} \mathrm{C}$. The radioactive signal was detected using a Molecular Dynamics (Sunnyvale, CA) Phosphorimager.

\section{Bacterial Adhesion to Arabidopsis Roots}

Agrobacterium strain $\mathrm{C} 58$ was grown to early stationary phase in Luria broth. Arabidopsis seeds were surface sterilized, vernalized at $4^{\circ} \mathrm{C}$ for 2 days, and then germinated and grown aseptically on MS agar plates for 1 to 2 weeks. The plants were gently pulled from the agar, and the roots were chopped with a scalpel in $2 \mathrm{~mL}$ of MS medium in a sterile 45-mm Petri dish. We next added $0.05 \mathrm{~mL}$ of the bacterial culture and incubated the chopped roots and bacteria together at room temperature for 24 to $48 \mathrm{hr}$. To examine the roots for bacterial attachment, we removed root pieces from the medium by draping them over a dissecting needle. The segments were suspended in a drop of water and examined and photographed using a Zeiss photoscope 2 (Oberkochen, West Germany) with Nomarski optics.

\section{Induction of Cellulose Synthesis by Cut Arabidopsis Plants}

We grew Arabidopsis plants for 2 to 4 weeks and chopped them in MS medium as described above. Cut pieces of the plants, including leaves and roots, were placed in dialysis tubing along with the MS medium in which the plants were chopped. The outside of the tubing was washed with sterile water and placed in $10 \mathrm{~mL}$ of MS medium in a sterile 125$\mathrm{mL}$ flask. To the flask was added $0.05 \mathrm{~mL}$ of a culture of Agrobacterium strain C58 grown overnight in Luria broth, and the flask was incubated at room temperature for 2 days. We poured the liquid surrounding the dialysis bag into a small Petri dish, examined the bacteria in the light microscope, and photographed the cellulose fibrils.

\section{ACKNOWLEDGMENTS}

We thank Dr. Vibha Gupta for heip with the genetic crosses, Dr. Sally Mackenzie for many useful discussions, and Drs. Walt Ream and Sally Mackenzie for critical reading of various versions of the manu- 
script. This work was supported in part by grants from the U.S. Department of Agriculture, No. 93-01215 and No. 95-37301-2040.

Received November 12, 1996; accepted January 13, 1997

\section{REFERENCES}

Akama, K., Shiraishi, H., Ohta, S., Nakamura, K., Okada, K., and Shimura, Y. (1992). Efficient transformation of Arabidopsis thaliana: Comparison of the efficiencies with various organs, plant ecotypes, and Agrobacterium strains. Plant Cell Rep. 12, 7-11.

Autsatz, W., and Grimm, C. (1994). A new, pathogen-inducible gene of Arabidopsis is expressed in an ecotype-specific manner. Plant Mol. Biol. 25, 229-239.

Bailey, M.A., Boerma, H.R., and Parrott, W.A. (1994). Inheritance of Agrobacterium tumefaciens-induced tumorigenesis in soybean. Crop Sci. 34, 514-519.

Bent, A.F., Innes, R.W., Ecker, J.R., and Staskawicz, B.J. (1992). Disease development in ethylene-insensitive Arabidopsis thaliana infected with virulent and avirulent Pseudomonas and Xanthomonas pathogens. Mol. Plant-Microbe Interact. 5, 372-378.

Bergmann, B.A., and Stomp, A.-M. (1992). Effect of host plant genotype and growth rate on Agrobacterium tumefaciens-mediated gall formation in Pinus radiata. Phytopathology 82, 1457-1462.

Binns, A.N., and Thomashow, M.F. (1988). Cell biology of Agrobacterium infection and transformation of plants. Annu. Rev. Microbiol. 42, 575-606.

Cangelosi, G.A., Hung, L., Puvanesarajah, V., Stacey, G., Ozga, D.A., Leigh, J.A., and Nester, E.W. (1987). Common loci for Agrobacterium tumefaciens and Rhizobium meliloti exopolysaccharide synthesis and their roles in plant interactions. J. Bacteriol. 169, 2086-2091.

Chaudhury, A.M., and Signer, E.R. (1989). Non-destructive transformation of Arabidopsis. Plant Mol. Biol. Rep. 7, 258-265.

Citovsky, V., Zupan, J., Warnick, D., and Zambryski, P. (1992) Nuclear localization of Agrobacterium VirE2 protein in plant cells. Science 256, 1802-1805.

Citovsky, V., Warnick, D., and Zambryski, P. (1994). Nuclear import of Agrobacterium VirD2 and VirE2 proteins in maize and tobacco. Proc. Natl. Acad. Sci. USA 91, 3210-3214.

Clarke, M.C., Wei, W., and Lindsey, K. (1992). High-frequency transformation of Arabidopsis thaliana by Agrobacterium tumefaciens. Plant Mol. Biol. Rep. 10, 178-189.

Dangl, J.L., Ritter, C., Gibbon, M.J., Mur, L.A.J., Wood, J.R., Goss, S., Mansfield, J., Taylor, J.D., and Vivian, A. (1992). Functional homologs of the Arabidopsis RPM1 disease resistance gene in bean and pea. Plant Cell 4, 1359-1369.

Davies, C., Howard, D., Tam, G., and Wong, N. (1994). Isolation of Arabidopsis thaliana mutants hypersensitive to gamma radiation. Mol. Gen. Genet. 243, 660-665.

Davis, K.R., Schott, E., and Ausubel, F.M. (1991). Virulence of selected phytopathogenic pseudomonads in Arabidopsis thaliana. Mol. Plant-Microbe Interact. 4, 477-488.
Debener, T., Lehnackers, H., Arnold, M., and Dangl, J.L. (1991). Identification and molecular mapping of a single Arabidopsis thaliana locus determining resistance to a phytopathogenic Pseudomonas syringae isolate. Plant J. 1, 289-302.

DeCleene, M., and DeLey, J. (1976). Range of crown gall. Bot. Rev. 42, 389-466.

Dellaporta, S.J. (1984). A plant minipreparation: Version II. Plant Mol. Biol. Rep. 1, 19-21.

Deng, W., Pu, X.-A., Goodman, R.N., and Nester, E.W. (1995). T-DNA genes responsible for inducing a necrotic response on grape vines. Mol. Plant-Microbe Interact. 8, 538-548.

Dong, X., Mindrinos, M., Davis, K.R., and Ausubel, F.M. (1991). Induction of Arabidopsis defense genes by virulent and avirulent Pseudomonas syringae strains and by a cloned avirulence gene. Plant Cell 3, 61-72.

Douglas, C.J., Halperin, W., and Nester, E.W. (1982). Agrobacterium tumefaciens mutants affected in attachment to plant cells. J. Bacteriol. 152, 1265-1275.

Feldmann, K.A. (1991). T-DNA insertion mutagenesis in Arabidopsis: Mutational spectrum. Plant J. 1, 71-82.

Feldmann, K.A., and Marks, M.D. (1987). Agrobacterium-mediated transformation of germinating seeds of Arabidopsis thaliana: A non-tissue culture approach. Mol. Gen. Genet. 208, 1-9.

Filichkin, S.A., and Gelvin, S.B. (1993). Formation of a putative relaxation intermediate during T-DNA processing directed by the Agrobacterium tumefaciens VirD1,D2 endonuclease. Mol. Microbiol. $\mathbf{8}$, 915-926.

Frisch, D.A., Harris-Haller, L.W., Yokubaitis, N.T., Thomas, T.L., Hardin, S.H., and Hall, T.C. (1995). Complete sequence of the binary vector Bin 19. Plant Mol. Biol. 27, 405-409.

Fuchs, H., and Sacristan, M.D. (1996). Identification of a gene in Arabidopsis thaliana controlling resistance to clubroot (Plasmodiophora brassicae) and characterization of the resistance response. Mol. Plant-Microbe Interact. 9, 91-97.

Gelvin, S.B. (1990). Crown gail disease and hairy root disease: A sledgehammer and a tackhammer. Plant Physiol. 92, 281-285.

Gelvin, S.B. (1992). Chemical signaling between Agrobacterium and its plant host. In Molecular Signals in Plant-Microbe Communications, D.P.S. Verma, ed (Boca Raton, FL: CRC Press), pp. 137-167.

Gheysen, G., Villarroel, R., and Van Montagu, M. (1991). Illegitimate recombination in plants: A model for T-DNA integration. Genes Dev. 5, 287-297.

Gurlitz, R.H.G., Lamb, P.W., and Matthysse, A.G. (1987). Involvement of carrot cell surface proteins in attachment of Agrobacterium tumefaciens. Plant Physiol. 83, 564-568.

Harlow, G.R., Jenkins, M.E., Pittalwala, T.S., and Mount, D.W. (1994). Isolation of uvh1, an Arabidopsis mutant hypersensitive to ultraviolet light and ionizing irradiation. Plant Cell 6, 227-235.

Herrera-Estrella, A., Van Montagu, M., and Wang, K. (1990). A bacterial peptide acting as a plant nuclear targeting signal: The amino-terminal portion of Agrobacterium VirD2 protein directs a $\beta$-galactosidase fusion protein into tobacco nuclei. Proc. Natl. Acad. Sci. USA 87, 9534-9537.

Holub, E.B., Brose, E., Tor, M., Clay, C., Grute, I.R., and Beynon, J.L. (1995). Phenotypic and genotypic variation in the interaction 
between Arabidopsis thaliana and Albugo candida. Mol. PlantMicrobe Interact. 8, 916-928.

Hood, E.E., Fraley, R.T., and Chilton, M.-D. (1987). Virulence of Agrobacterium tumefaciens strain A281 on legumes. Plant Physiol. 83, 529-534.

Hooykaas, P.J.J., and Beijersbergen, A.G.M. (1994). The virulence system of Agrobacterium tumefaciens. Annu. Rev. Phytopathol. 32, 157-179.

Howard, E., and Citovsky, V. (1990). The emerging structure of the Agrobacterium T-DNA transfer complex. Bioessays 12, 103-108

Howard, E., Zupan, J.R., Citovsky, V., and Zambryski, P.C. (1992). The VirD2 protein of $A$. tumefaciens contains a C-terminal bipartite nuclear localization signal: Implications for nuclear uptake of DNA in plant cells. Cell 68, 109-118.

Janssen, B.J., and Gardner, R.C. (1989). Localized transient expression of GUS in leaf discs following cocultivation with Agrobacterium. Plant Mol. Biol. 14, 61-72.

Jefferson, R.A., Kavanagh, T.A., and Bevan, M.W. (1987). GUS fusions: $\beta$-Glucuronidase as a sensitive and versatile gene fusion marker in higher plants. EMBO J. 6, 3901-3907.

Koch, E., and Slusarenko, A. (1990). Arabidopsis is susceptible to infection by a downy mildew fungus. Plant Cell 2, 437-445.

Koncz, C., and Schell, J. (1986). The promoter of TL-DNA gene 5 controls the tissue-specific expression of chimaeric genes carried by a novel type of Agrobacterium binary vector. Mol. Gen. Genet. 204, 383-396.

Koukolikova-Nicola, Z., Raineri, D., Stephens, K., Ramos, C., Tinland, B., Nester, E.W., and Hohn, B. (1993). Genetic analysis of the virD operon of Agrobacterium tumefaciens: A search for functions involved in transport of T-DNA into the plant cell nucleus and in T-DNA integration. J. Bacteriol. 175, 723-731.

Kuldau, G.A., De Vos, G., Owen, J., McCaffrey, G., and Zambryski, P. (1990). The virB operon of Agrobacterium tumefaciens pTiC58 encodes 11 open reading frames. Mol. Gen. Genet. 221, 256-266.

Lee, S., Stenger, D.C., Bisaro, D.M., and Davis, K.R. (1994). Identification of loci in Arabidopsis that confer resistance to geminivirus infection. Plant J. 6, 525-535.

Leisner, S.M., and Howell, S.H. (1992). Symptom variation in different Arabidopsis thaliana ecotypes produced by cauliflower mosaic virus. Phytopathology 82, 1042-1046.

Leisner, S.M., Turgeon, R., and Howell, S.H. (1993). Effects of host plant development and genetic determinants on the longdistance movement of cauliflower mosaic virus in Arabidopsis. Plant Cell 5, 191-202.

Lichtenstein, C., and Draper, J. (1986). Genetic engineering of plants. In DNA Cloning: A Practical Approach, Vol. 2, D.M. Glover, ed (Oxford, UK: IRL Press), pp. 67-119.

Liu, C.-N., Li, X.-Q., and Gelvin, S.B. (1992). Multiple copies of virG enhance the transient transformation of celery, carrot, and rice tissues by Agrobacterium tumefaciens. Plant Mol. Biol. 20, 1071-1087.

Lloyd, A.M., Barnason, A.R., Rogers, S.G., Byrne, M.C., Fraley, R.T., and Horsch, R.B. (1986). Transformation of Arabidopsis thaliana with Agrobacterium tumefaciens. Science 234, 464-466.
Mandal, A., Lang, V., Orczyk, W., and Palva, E.T. (1993). Improved efficiency for T-DNA-mediated transformation and plasmid rescue in Arabidopsis thaliana. Theor. Appl. Genet. 86, 621-628.

Matsumoto, S., Ito, Y., Hosoi, T., Takahashi, Y., and Machida, Y. (1990). Integration of Agrobacterium T-DNA into a tobacco chromosome: Possible involvement of DNA homology between T-DNA and plant DNA. Mol. Gen. Genet. 224, 309-316.

Matthysse, A.G. (1987). Characterization of nonattaching mutants of Agrobacterium tumefaciens. J. Bacteriol. 169, 313-323.

Matthysse, A.G. (1994). Conditioned medium promotes the attachment of Agrobacterium tumefaciens strain NT1 to carrot cells. Protoplasma 183, 131-136.

Matthysse, A.G., Lightfoot, R., and White, S. (1995). Genes required for cellulose synthesis in Agrobacterium tumefaciens. J. Bacteriol. 177, 1069-1075.

Mauro, A.O., Pfeiffer, T.W., and Collins, G.B. (1995). Inheritance of soybean susceptibility to Agrobacterium tumefaciens and its relationship to transformation. Crop Sci. 35, 1152-1156.

Mayerhofer, R., Koncz-Kalman, Z., Nawrath, C., Bakkeren, G., Crameri, A., Angelils, K., Redei, G.R., Schell, J., Hohn, B., and Koncz, C. (1991). T-DNA integration: A mode of illegitimate recombination in plants. EMBO J. 10, 697-704.

Miller, J.H. (1972). Experiments in Molecular Genetics. (Cold Spring Harbor, NY: Cold Spring Harbor Laboratory).

Murashige, T., and Skoog, F. (1962). A revised medium for rapid growth and bioassays with tobacco tissue cultures. Physiol. Plant. $15,473-497$.

Narasimhulu, S.B., Deng, X.-b., Sarria, R., and Gelvin, S.B. (1996). Early transcription of Agrobacterium T-DNA genes in tobacco and maize. Plant Cell 8, 873-886.

Neff, N.T., and Binns, A.N. (1985). Agrobacterium tumefaciens interaction with suspension-cultured tomato cells. Plant Physiol. 77, 35-42:

Ni, M., Cui, D., Einstein, J., Narasimhulu, S., Vergara, C.E., and Gelvin, S.B. (1995). Strength and tissue specificity of chimeric promoters derived from the octopine and mannopine synthase genes. Plant J. 7, 661-676.

Ohba, T., Yoshioka, Y., Machida, C., and Machida, Y. (1995). DNA rearrangement associated with the integration of T-DNA in tobacco: An example for multiple duplications of DNA around the integration target. Plant J. 7, 157-164.

Owens, L.D., and Cress, D.E. (1984). Genotypic variability of soybean response to Agrobacterium strains harboring the $\mathrm{Ti}$ or $\mathrm{Ri}$ plasmids. Plant Physiol. 77, 87-94.

Pu, X.-A., and Goodman, R.N. (1992). Induction of necrosis by Agrobacterium tumefaciens on grape explants. Physiol: Mol. Plant Pathol. 41, 245-254.

Ream, W. (1989). Agrobacterium tumefaciens and interkingdom genetic exchange. Annu. Rev. Phytopathol. 27, 583-618.

Robbs, S.L., Hawes, M.C., Lin, H.-J., Pueppke, S.G., and Smith, L.Y. (1991). Inheritance of resistance to crown gall in Pisum sativum. Plant Physiol. 95, 52-57.

Rossi, L., Hohn, B., and Tinland, B. (1993). The VirD2 protein of Agrobacterium tumefaciens carries nuclear localization signals important for transfer of T-DNA to plants. Mol. Gen. Genet. 239, 345-353. 
Sangwan, R.S., Bourgeois, Y., and Sangwan-Norreel, B.S. (1991). Genetic transformation of Arabidopsis thaliana zygotic embryos and identification of critical parameters influencing transformation efficiency. Mol. Gen. Genet. 230, 475-485.

Sangwan, R.S., Bourgeois, Y., Brown, S., Vasseur, G., and Sangwan-Norreel, B. (1992). Characterization of competent cells and early events of Agrobacterium-mediated genetic transformation in Arabidopsis thaliana. Planta 188, 439-456.

Schmidt, R., and Willmitzer, L. (1988). High efficiency Agrobacterium tumefaciens-mediated transformation of Arabidopsis thaliana leaf and cotyledon explants. Plant Cell Rep. 7, 583-586.

Sciaky, D., Montoya, A.L., and Chilton, M.-D. (1978). Fingerprints of Agrobacterium Ti plasmids. Plasmid 1, 238-253.

Shurvinton, C.E., Hodges, L., and Ream, W. (1992). A nuclear localization signal and the C-terminal omega sequence in the Agrobacterium tumefaciens VirD2 endonuclease are important for tumor formation. Proc. Natl. Acad. Sci. USA 89, 1837-1841.

Simon, A.E., Li, X.H., Lew, J.E., Strange, R., Zhang, C., Polacco, M., and Carpenter, C.D. (1992). Susceptibility and resistance of Arabidopsis thaliana to turnip crinkle virus. Mol. Plant-Microbe Interact. 5, 496-503.

Simpson, R.B., and Johnson, L.J. (1990). Arabidopsis thaliana as a host for Xanthomonas campestris pv. campestris. Mol. PlantMicrobe Interact. 3, 233-237.

Smarrelli, J., Watters, M.T., and Diba, L.H. (1986). Response of various cucurbits to infection by plasmid-harboring strains of Agrobacterium. Plant Physiol. 82, 622-624.

Sonti, R.V., Chiurazzi, M., Wong, D., Davies, C.S., Harlow, G.R., Mount, D.W., and Signer, E.R. (1995). Arabidopsis mutants deficient in T-DNA integration. Proc. Natl. Acad. Sci. USA 92, 11786-11790.

Stachel, S.E., and Nester, E.W. (1986). The genetic and transcriptional organization of the vir region of the A6 Ti plasmid of Agrobacterium tumefaciens. EMBO J. 5, 1445-1454.

Stachel, S.E., Messens, E., Van Montagu, M., and Zambryski, P. (1985). Identification of the signal molecules produced by wounded plant cells that activate T-DNA transfer in Agrobacterium tumefaciens. Nature 318, 624-629.

Stachel, S.E., Timmerman, B., and Zambryski, P. (1986). Generation of single-stranded T-DNA molecules during the initial stages of T-DNA transfer from Agrobacterium tumefaciens to plant cells. Nature 322, 706-712.

Szegedi, E., and Kozma, P. (1984). Studies on the inheritance of resistance to crown gall disease of grapevine. Vitis 23, 121-126.
Thomashow, M.F., Karlinsey, J.E., Marks, J.R., and Hurlbert, R.E. (1987). Identification of a new virulence locus in Agrobacterium tumefaciens that affects polysaccharide composition and plant cell attachment. J. Bacteriol. 169, 3209-3216.

Thompson, D.V., Melchers, L.S., Idler, K.B., Schilperoort, R.A., and Hooykaas, P.J.J. (1988). Analysis of the complete nucleotide sequence of the Agrobacterium tumefaciens virB operon. Nucleic Acids Res. 16, 4621-4636.

Tinland, B., Koukolikova-Nicola, Z., Hall, M.N., and Hohn, B. (1992). The T-DNA-linked VirD2 protein contains two distinct functional nuclear localization signals. Proc. Natl. Acad. Sci. USA 89, 7442-7446.

Tinland, B., Hohn, B., and Puchta, H. (1994). Agrobacterium tumefaciens transfers single-stranded transferred DNA (T-DNA) into the plant cell nucleus. Proc. Natl. Acad. Sci. USA 91, 8000-8004.

Tsuji, J., Somerville, S.C., and Hammerschmidt, R. (1991). Identification of a gene in Arabidopsis thaliana that controls resistance to Xanthomonas campestris pv. campestris. Physiol. Mol. Plant Pathol. 38, 57-65.

Valvekens, D., Van Montagu, M., and Van Lijsebettens, M. (1988). Agrobacterium tumefaciens-mediated transformation of Arabidopsis thaliana root explants by using kanamycin selection. Proc. Natl. Acad. Sci. USA 85, 5536-5540.

Ward, J.E., Akiyoshi, D.E., Regier, D., Datta, A., Gordon, M.P., and Nester, E.W. (1988). Characterization of the virB operon from an Agrobacterium tumefaciens Ti plasmid. J. Biol. Chem. 263, 5804-5814.

Whalen, M.C., Innes, R.W., Bent, A.F., and Staskawicz, B.J. (1991). Identification of Pseudomonas syringae pathogens of Arabidopsis and a bacterial locus determining avirulence on both Arabidopsis and soybean. Plant Cell 3, 49-59.

Winans, S.C. (1992). Two-way chemical signaling in Agrobacterium-plant interactions. Microbiol. Rev. 56, 12-31.

Yu, G.-L., Katagiri, F., and Ausubel, F.M. (1993). Arabidopsis mutations at the RPS2 locus result in loss of resistance to Pseudomonas syringae strains expressing the avirulence gene avrRpt2. Mol. Plant-Microbe Interact. 6, 434-443.

Yusibov, V.M., Steck, T.R., Gupta, V., and Gelvin, S.B. (1994). Association of single-stranded transferred DNA from Agrobacterium tumefaciens with tobacco cells. Proc. Natl. Acad. Sci. USA 91, 2994-2998.

Zupan, J.R., and Zambryski, P. (1995). Transfer of T-DNA from Agrobacterium to the plant cell. Plant Physiol. 107, 1041-1047. 
Differences in susceptibility of Arabidopsis ecotypes to crown gall disease may result from a deficiency in T-DNA integration.

J Nam, A G Matthysse and S B Gelvin

Plant Cell 1997;9;317-333

DOI 10.1105/tpc.9.3.317

This information is current as of July 22, 2020

Permissions

eTOCs

CiteTrack Alerts

Subscription Information
https://www.copyright.com/ccc/openurl.do?sid=pd_hw1532298X\&issn=1532298X\&WT.mc_id=pd_hw153229 $8 \mathrm{X}$

Sign up for eTOCs at:

http://www.plantcell.org/cgi/alerts/ctmain

Sign up for CiteTrack Alerts at:

http://www.plantcell.org/cgi/alerts/ctmain

Subscription Information for The Plant Cell and Plant Physiology is available at: http://www.aspb.org/publications/subscriptions.cfm 